\title{
Montana Law Review
}

8-1-2019

\section{A Legal Response to the Sovereign Citizen Movement}

Caesar Kalinowski IV

Caesar Kalinowski IV, Commercial Litigator, Davis Wright Tremaine LLP

Follow this and additional works at: https://scholarworks.umt.edu/mlr

Part of the Law Commons

Let us know how access to this document benefits you.

\section{Recommended Citation}

Caesar Kalinowski IV, A Legal Response to the Sovereign Citizen Movement, 80 Mont. L. Rev. 153 (2019).

This Article is brought to you for free and open access by ScholarWorks at University of Montana. It has been accepted for inclusion in Montana Law Review by an authorized editor of ScholarWorks at University of Montana. For more information, please contact scholarworks@mso.umt.edu. 


\begin{tabular}{lllll}
\hline |ljciprod01/productnIMIMON|80-2\MON202.txt & unknown & Seq: 1 & 1-AUG-19 & $11: 52$ \\
\hline
\end{tabular}

\title{
ARTICLES
}

\section{A LEGAL RESPONSE TO THE SOVEREIGN CITIZEN MOVEMENT}

\author{
Caesar Kalinowski IV*
}

"A little knowledge is a dangerous thing. It may also prove costly."

\section{INTRODUCTION}

In early 2016, armed antigovernment protesters led by Ammon Bundy occupied the Malheur National Wildlife Refuge in Harney County, Oregon, to challenge the federal government's control over public lands. ${ }^{2}$ By February, federal and state law enforcement officers had arrested or killed all members of the group; those arrested were later charged with a number of federal offenses. ${ }^{3}$ At trial, the defendants claimed that the United States did not have jurisdiction over the wildlife refuge. ${ }^{4}$ Despite a 1935 Supreme Court opinion holding otherwise, the defendants argued that the state of Oregon was the true owner of the land since its incorporation..$^{5}$ By October, an Oregon jury acquitted Bundy and the others of the federal conspiracy and weapons charges against them-a result many believe can be explained

* Caesar Kalinowski IV is a commercial litigator with Davis Wright Tremaine LLP, as well as an avid First Amendment and federalism supporter. Caesar wishes to thank Jenny Mendoza, Benjamin Nelson, Kaleigh Powell, and Donald Netolitzky for their invaluable feedback and assistance; and his wife and son for their endless support.

1. Montana Pole \& Treating Plant v. I.F. Laucks \& Co., 993 F.2d 676, 677 (9th Cir. 1993).

2. Harrison Berry, Militia Group Seizes Malheur National Wildlife Refuge Headquarters, BoIsE WEEKLY (Jan. 3, 2016), https://perma.cc/VMW6-WYHS.

3. Steven Dubois, Ammon Bundy, Others Face New Charges in Oregon Standoff, StATESMAN Journal (Mar. 9, 2016, 5:09 PM PDT), https://perma.cc/HV2G-FS6H.

4. Ammon Bundy Offered Guilty Plea if Armed Oregon Protesters Were Let Go, RT QuESTION More (Apr. 28, 2016), https://perma.cc/RMW9-2V7A.

5. United States v. Oregon, 295 U.S. 1, 29 (1935). 


\begin{tabular}{lllll}
\hline |ljciprod01\productn\M\MON\80-2\MON202.txt & unknown & Seq: 2 & 1-AUG-19 & $11: 52$ \\
\hline
\end{tabular}

only as jury nullification. ${ }^{6}$ While some believe that the underlying basis for the group's claims have far-reaching implications for the meaning and foundation of the federal government's power, in reality, groups like Bundy's simply misread, misconstrue, and misunderstand the United States Constitution.

The defendants' assertions are not new. They are simply the most recent example of a pervasive movement involving unique views on the constitutionality of the United States' jurisdiction and ability to punish or tax its citizens. While the various groups have differing names and ideologies, the vast majority in the United States" can be classified as "Sovereign Citizens." ${ }^{\text {Th }}$ The FBI describes Sovereign Citizens as "anti-government extremists who believe that even though they physically reside in this country, they are separate or 'sovereign' from the United States." Evolving from "a combination of four different movements: the Tax Protester movement, the Posse Comitatus, the Patriot movement, and Common-Law Courts," 10 the Sovereign Citizen movement began in the 1960s and gained adherents well into the 1990s. Following the economic downturn of 2008, the movement saw a resurgence. ${ }^{11}$ In fact, despite no unifying leader or firmly established tenets, the Southern Poverty Law Center estimates that there are over 300,000 Sovereign Citizens in America today. ${ }^{12}$ Although this number has been called into question, ${ }^{13}$ the fact remains that thousands of adherents exist.

Most often, Sovereign Citizens contest the United States' jurisdiction over them as federal defendants because they have not consented to that jurisdiction. In pursuing their "rights," Sovereign Citizens engage in "paper

6. Courtney Sherwood \& Kirk Johnson, Bundy Brothers Acquitted in Takeover of Oregon Wildlife Refuge, N.Y. Times (Oct. 27, 2016), https://perma.cc/D23F-Q87S.

7. This phenomenon is not limited to the United States, and many common law nations have their own version of Sovereign Citizens. See Donald Netolitzky, A Pathogen Astride the Minds of Men: The Epidemiological History of Pseudolaw, CEFIR Symposium: Sovereign Citizens In CANAda (May 3, 2018), https://perma.cc/ WXT9-L39D; see also Meads v. Meads, 2012 ABQB 571 (Can.).

8. For a comprehensive overview of the various groups' origins and beliefs, see Michael Mastrony, Common-Sense Responses to Radical Practices: Stifling Sovereign Citizens in Connecticut, 48 Conn. L. Rev. 1013, 1017-20 (2016); Joshua P. Weir, Sovereign Citizens: A Reasoned Response to the Madness, 19 Lewis \& Clark L. Rev. 829, 836 (2015).

9. Domestic Terrorism, The Sovereign Citizen Movement, Federal Bureau of Investigation (Apr. 13, 2010), https://perma.cc/L8SQ-2K42 [hereinafter Domestic Terrorism].

10. Mastrony, supra note 8, at 1017.

11. See Stephen A. Ken, Freemen, Sovereign Citizens, and the Challenge to Public Order in British Heritage Countries, European Federation of Centres of Research and Information on SectariANISM (May 30, 2013), https://perma.cc/7NLV-PZPP (arguing that there appears to be a link between broader applications of pseudolaw and economic stress).

12. Sovereign Citizens Movement, Southern Poverty Law Center, https://perma.cc/Z7RG83QR.

13. See Michelle Mallek, Uncommon Law: Understanding and Quantifying the Sovereign Citizen Movement, Naval Postgraduate School (2016), https://perma.cc/4E8V-38U9. 
terrorism," which includes the filing of false liens against government officials and a multitude of other civil claims based on abstract violations of the Uniform Commercial Code ("UCC"). ${ }^{14}$ These tactics impose tremendous hardship on civil servants, both in terms of "monetary expenditures and of staff psychological stress." 15

Sometimes conflicts between Sovereign Citizens and the government end in bloodshed. ${ }^{16}$ The 2010 West Memphis police shooting involving Jerry and Joseph Kane is but one gruesome example of the Sovereign Citizen philosophy escalating to violence. ${ }^{17}$ Due to increasing attacks, the FBI has classified the movement as a "domestic terrorist threat," finding that members "[c]ommit murder and physical assault; [t]hreaten judges, law enforcement professionals, and government personnel; [i]mpersonate police officers and diplomats; [u]se fake currency, passports, license plates, and driver's licenses; and [e]ngineer various white-collar scams[.]"18 Noting a significant shift, the FBI's Counterterrorism Analysis Section believes that some Sovereign Citizens are moving from "reacting to law enforcement scrutiny to targeting police officers[,] indicat[ing] an increased interest in harassing and intimidating police [that] may lead to potentially hostile confrontations." 19 In fact, in a recent comprehensive survey of law enforcement agencies, law enforcement officers perceived Sovereign Citizens to be a more serious terrorist threat than Islamic extremists. ${ }^{20}$

Although identifying the tactics used by the Sovereign Citizen movement is fairly easy, succinctly defining its beliefs and aims can be exceedingly difficult. Sovereign Citizens have no leader, no central repository for ideas, and no unifying collective mission. Most adherents get their information through nebulous webpages or YouTube videos. Generally, Sovereign

14. David Fleishman, Paper Terrorism: The Impact of the "Sovereign Citizen" on Local Government, 27 PuB. L.J., no. 2, Spring 2004, at 7, https://perma.cc/KLF7-AFC4.

15. Fleishman, Paper Terrorism, supra note 14, at 7.

16. Amir Vera, Waffle House Shooter Was Once Arrested by Secret Service for Trespassing Near White House, CNN (Apr. 22, 2018), https://perma.cc/HF2G-XTVX (Waffle House shooter Travis Reinking); Jason Wilson, New Documents Suggest Las Vegas Shooter Was Conspiracy Theorist-What We Know, The Guardian (May 19, 2018), https://perma.cc/47SU-2DN2 (Las Vegas shooter Stephen Paddock); Gavin Long, Baton Rouge Gunman, Was a Sovereign Citizen, Newsweek (July 18, 2016), https://perma.cc/7DEA-CE3D (Baton Rouge shooter Gavin Long).

17. Dan Harris, Deadly Arkansas Shooting by "Sovereigns" Jerry and Joe Kane Who Shun U.S. Law, ABC News (July 1, 2010), https://perma.cc/A5FZ-GX55.

18. Domestic Terrorism, supra note 9.

19. Recent Sovereign Citizen Extremist Targeting of Law Enforcement Highlights Potential for Violence During Traffic Stops, Federal Bureau of Investigation (June 1, 2012), https://perma.cc/ R9QX-C9X9.

20. See David Carter, Steve Chermak, Jeremy Carter, \& Jack Drew, Understanding Law Enforcement Intelligence Processes: Report to the Office of University Programs, Science and Technology Directorate, United States Department of Homeland Security (July 2014), https://perma.cc/WCJ4TJYM. 
Citizens believe that the Fourteenth Amendment of the Constitution created a second form of citizenship that "enslaved" or created a contract with the population under a federal corporation. ${ }^{21}$ An extension of this belief asserts that the United States went bankrupt in 1933 and subsequently, the government "borrowed" collateral by using the future earnings of citizens to back its currency. ${ }^{22}$ As part of these beliefs, members seek to "disassociate" or "divest" the "legally fictional persons" from their "natural persons" to remove the United States' jurisdiction and financially take advantage of their inherent sovereignty. ${ }^{23}$

One could easily dismiss these claims as conspiracy theories, but such a terse response would betray one important point: the Sovereign Citizen movement is made up of thousands of U.S. citizens that distrust the federal government and are actively trying to limit its power through reference to the Constitution. Although their means run the gamut from frivolous to downright dangerous, the Sovereign Citizen movement is growing by the day. ${ }^{24}$

For the judges, prosecutors, and civil servants that regularly engage with these groups, dealing with incoherent legal arguments can be daunting. Sovereign Citizens' arguments do not follow traditional legal logic, yet they need to be coherently addressed. Consolidating the claims alone can be extremely difficult, ${ }^{25}$ as a lack of uniformity in beliefs as well as differing "interpretations" makes pinning down the actual doctrine nearly impossible. Perhaps because of this conundrum, courts and public servants interacting with Sovereign Citizens generally dismiss Sovereign Citizens' claims as meritless without examining or explaining why. ${ }^{26}$ Because "[w]e live in a

21. Jerome P. Bjelopera, The Domestic Terrorist Threat: Background and Issues for Congress, Congressional Research Service (Jan. 17, 2013), https://perma.cc/H4J7-3ZU8.

22. Sovereign Citizen Movement: Extremists Claim to be "Beyond the Law", Regional Organized Crime Information Center Special Research Report (2010), https://perma.cc/X5U4-A6XM.

23. See Paul Davies \& Kirk Rutter, Meet Your Strawman 3:30-3:56, YouTube (June. 19, 2010), available at https://www.youtube.com/watch?v=8rGyqDkqSXI (last visited Feb. 16, 2019); Intelligence Rep. Staff, New Multi-Million Dollar Scam Takes Off in Antigovernment Circles, Southern Poverty LAw Center (Dec. 18, 2002), https://perma.cc/8TFC-STX5; The Sovereigns: A Dictionary of the Peculiar, Southern Poverty Law Center (Aug. 1, 2010), https://perma.cc/P9TT-2C8X [hereinafter The Sovereigns].

24. Sovereign Citizens Movement, supra note 12.

25. Acknowledging that finding one unified system of Sovereign Citizen beliefs is impossible, I have drawn from a multitude of sources and websites such as "U.S.A. The Republic," which contain the basic - and most often invoked-tenets of the Sovereign Citizen movement.

26. See, e.g., United States v. Coleman, 871 F.3d 470, 476 (6th Cir. 2017) ("Defendant's legal arguments directly correspond to meritless rhetoric frequently espoused by tax protesters, sovereign citizens, and self-proclaimed Moorish-Americans.”); Gravatt v. United States, 100 Fed. Cl. 279, 286 (2011); United States v. Benabe, 654 F.3d 753, 769 (7th Cir. 2011) (recounting "campaign of obstreperous interruptions and frivolous legal arguments"); United States v. Hart, 701 F.2d 749, 750 (8th Cir. 1983) (“This appeal is frivolous."); but see Bey v. State, 847 F.3d 559, 561 (7th Cir. 2017) (discussing 
time of great cynicism about the institutions of American government,"27 public servants that work in the executive and judicial branches should endeavor to inform the public of their actual constitutional rights-misguided and frivolous as some citizens' objections may be.

This article seeks to provide civil servants, law enforcement, and the judiciary with a comprehensive reference guide to the Sovereign Citizen movement. To do this, the article attempts to make sense of and explain the most common Sovereign Citizen themes and their failings under the Constitution: first, the jurisdiction of the federal government over actual flesh and blood citizens; second, the ability to tax citizens and redeeming the "strawman" (the so-called "Redemption Scheme"); and third, the individual's right to travel. ${ }^{28}$ By explaining the legal shortcomings of the Sovereign Citizen ideology, lawyers and judges can address citizens' concerns about government overreach, dissuade Sovereign Citizens themselves from continually reasserting the same meritless arguments, and inform the general public of their actual constitutional rights.

\section{Discussion}

First and foremost, Sovereign Citizens believe that the United States Government has no inherent power over individual citizens of the various states without individual consent. ${ }^{29}$ This concept, which I will call the "Natural Persons" theory, is the most commonly espoused principle that Sovereign Citizens rely on to make their legal claims. The Redemption Scheme and the unfettered right to travel are extensions of the Natural Persons theory, in that (1) they seek to reclaim their "strawman's" hidden trust accounts established by the government and (2) they believe that only a corporate artificial person can consent to regulation under state or federal driving laws. Despite these seemingly earnest interpretations of the law, however, the Constitution and the Supreme Court's jurisprudence provide no support for the Natural Persons theory, Redemption Scheme, or an unfet-

the Moorish and Sovereign Citizen movement with an aim "to introduce readers who may not be familiar with the 'sovereign citizen' movement to its principal institutional establishment").

27. Erwin Chemerinsky, The Supreme Court, Public Opinion, and the Role of the Academic Commentator, 40 S. TEx. L. Rev. 943, 944 (1999).

28. I acknowledge that for lawyers and lay persons alike, the Sovereign Citizens' arguments presented here can be baffling. They often defy basic legal tenets and logic. I endeavor to explain each argument as coherently — and faithfully — as possible, providing direct language from Sovereign Citizen sources in the footnotes.

29. While the reason for this fear has yet to be examined, it is likely the result of feelings of economic instability. See Stephen Garrett Smith, An Analysis of the Sovereign Citizen Movement: Demographics and Trial Behaviors 4-6 (May 2016) (dissertation, University of Arkansas, Fayetteville), https://perma.cc/H7EC-46FF; Angela P. Harris, Vultures in Eagles' Clothing: Conspiracy and Racial Fantasy in Populist Legal Thought, 10 Мich. J. RACE \& L. 269, 270 (2005). 
tered right to travel. Accordingly, I first examine the Sovereign Citizens' claims, followed by legal refutations of the principles that underlie each claim.

\section{A. Jurisdiction}

\section{1. "Natural" versus "Artificial” persons}

In short, Sovereign Citizens believe that the "U.S. citizen, is a legal fiction that has been created by the federal government, via the social security application, and is a corporate employee of the United States by virtue of being a U.S. citizen." ${ }^{30}$ This artificial person alone "is subject to the jurisdiction of the federal government and of the state government and subject to the corporate income tax." 31 Accordingly, only by consenting to a Fourteenth Amendment-based federal citizenship is an individual governed by the United States Government. ${ }^{32}$ Additionally, if an individual "renounces" his or her federal citizenship and divests the "legally fictitious person" through a series of complex steps, then the government has no power over the "Natural Person." 33 Due in part to the identification of a "legally fictitious person" as distinct from a "natural person," Sovereign Citizens place special emphasis on the use of nouns, capitalization, and surnames to support and articulate their theory. ${ }^{34}$ For example, when filing motions or pleadings, Sovereign Citizens may refer to themselves as "I, a Man, of the Family [defendant's surname], representing the Artificial Personhood of [defendant's name in full capital letters]." 35

The basis for the Natural Persons theory stems from the belief that "every individual born in one of the 50 sovereign states was born an individual American sovereign, with inalienable rights." 36 Specifically, the "pursuit of happiness" (as defined by Sovereign Citizens) includes "the right to engage in a common occupation or business without a license, to travel freely from one place to another without permission from the state

30. The TRUTH About the 14th Amendment or Who Are You, Really?, U.S.A. THE REPUBLIC (Mar. 4, 2012), https://perma.cc/6DKL-Y54S [hereinafter The TRUTH 1].

31. Id.

32. Id.

33. The Sovereigns, supra note 23.

34. See Debra Cassens Weiss, Judge of Bogus 'Postal Court' Files Judgments, Claims Only Nouns Have Legal Meaning, ABA Journal (Mar. 22, 2016), https://perma.cc/5XRH-NW42; Joshua P. Weir, Sovereign Citizens: A Reasoned Response to the Madness, 19 Lewis \& Clark L. Rev. 829, 867 (2015) (citing James Erickson Evans, The "Flesh and Blood" Defense, 53 WM. \& MARy L. Rev. 1361, 1363 (2012)); The Sovereigns, supra note 23.

35. See Pho Chang, Why Your Legal Name is Written in All Capital Letters, OMNITHOUGHT.org (May 9, 2015), https://perma.cc/2YQG-2FRL.

36. Tom Morton, Sovereign Citizens Renounce First Sentence of 14th Amendment, CASPER STARTribune (Apr. 17, 2011), https://perma.cc/BV8G-HE8Z; The TRUTH 1, supra note 30. 
(driver's license), the inalienable right to acquire and possess property without paying property tax, etc." 37

Citing Chisholm v. Georgia, ${ }^{38}$ an antebellum precedent, Sovereign Citizens claim that because the federal government "may acquire property distinct from that of its members [and] may incur debts," the Government is an artificial person. ${ }^{39}$ A Sovereign Citizen, however, is a free man made of flesh and blood, and can only be subject to laws that the natural person has consented to abide by ${ }^{40}$ Accordingly, "you," as a person "waive your sovereign status, to become a subject ... [b]y contracting with the government and accepting benefits." 41 The natural person that has consented is "known as [an] American Citizen, with a capital 'C'." 42

Sovereign Citizens find additional support for the Natural Persons theory from the Reconstruction era amendments to the Constitution. Sovereign Citizens believe that the Thirteenth Amendment, which outlawed slavery, caused problems for the federal government because up until that point, "slaves were not citizens of any state or country, because they were just property, and property did not have citizenship." 43 To rectify this problem, according to Sovereign Citizens, the Fourteenth Amendment was ratified so as to create "a new class of citizenship." 44 This new citizenship was a "privilege" granted by the federal government, unsupported by the "sovereign inalienable right." 45 This new class of citizen, which included former slaves, is believed to have been made up of "artificial persons" that "contract" with the federal government to gain certain federally-protected rights. ${ }^{46}$

In support of this theory, Sovereign Citizens rely on the plain text of the Fourteenth Amendment, Section 1, which states:

All persons born or naturalized in the United States and subject to the jurisdiction thereof, are citizens of the United States and of the State wherein they reside. No State shall make or enforce any law which shall abridge the privileges or immunities of citizens of the United States; nor shall any State

37. The TRUTH 1, supra note 30.

38. Chisholm v. Georgia, 2 U.S. (2 Dall.) 419, 455 (1793), overruled by U.S. Const. amend XI., superseded by Pennhurst State School \& Hosp. v. Halderman, 465 U.S. 89, 97-98 (1984).

39. The TRUTH 1, supra note 30 (citing Chisholm, 2 U.S. (2 Dall.) at 455).

40. Id. (citing Chisholm, 2 U.S. (2 Dall.) at 456 ("The only reason, I believe, why a free man is bound by human laws, it that he binds himself.")).

41. Id. ("The only way the government will contract with you, is if you waive your inalienable rights and agree to be UNDER their jurisdiction.").

42. Id.

43. Id.

44. Id.

45. Id. (noting that "the U.S. citizen is spelled with a lower case ' $c$ '. This is to show a lower class of citizenship.").

46. 14th Amendment Citizen vs Sovereign Constitutional Citizen 2:00-4:30 YouTube (May 8, 2015), available at $\mathrm{https}: / / \mathrm{www} . y o u t u b e . c o m / w a t c h ? v[5 \mathrm{hr} 4 \mathrm{WlJ}-\mathrm{w}$. 
deprive any person of life, liberty, or property, without due process of law; nor deny to any person within its jurisdiction the equal protection of the laws. 47

Breaking the plain language into two sub-sections, Sovereign Citizens first interpret the phrase "[a]ll persons born or naturalized in the United States and subject to the jurisdiction thereof, are citizens of the United States and of the State wherein they reside." 48 With regard to the word "persons," Sovereign Citizens believe that there are both "natural persons" (who are the actual physical individuals who have sovereign and inalienable rights by birth) and "artificial persons" (like the government, or citizens under the Fourteenth Amendment, with only government-created rights). ${ }^{49}$ Because the collective citizenry created the "artificial person" of the federal government by giving birth to it, that artificial person (the Government) cannot purport to assume control over the "natural persons" by amendment of the Constitution. ${ }^{50}$

As a result, the "persons" referred to in the Fourteenth Amendment can only logically be referring to "artificial persons" that are created under the new class of citizenship. Further "evidence" that the Fourteenth Amendment only governs "artificial persons" allegedly exists in the use of "the United States" and "jurisdiction." Sovereign Citizens believe that if the Fourteenth Amendment had intended to govern the "citizens" of the various states, then the language would have read "the United States of America," implying all of the states and not merely the government itself. ${ }^{51}$ Moreover, the use of the singular "jurisdiction," as opposed to "jurisdictions," also allegedly shows that the Amendment only considered the singular entity of the federal government as opposed to all the jurisdictions and entities of the various states. ${ }^{52}$

Sovereign Citizens next erroneously interpret the phrase "No State shall make or enforce any law which shall abridge the privileges or immunities of citizens of the United States[.]"53 They believe that the privileges and immunities referred to here are those of the "American Citizen" as a sovereign individual, whose rights are not granted by the Constitution but are rather secured by it. ${ }^{54}$ The real grant is recognized in the Declaration of Independence, which states that these sovereign individuals "are endowed

47. U.S. Const. amend. XIV, § 1.

48. Id. (emphasis added).

49. The TRUTH 1, supra note 30.

50. Id.; M.R. Hamilton, Supreme Court Rules Two United States, AFreeCountry.com (Mar. 29, 2014), https:// perma.cc/8TXW-S2C7.

51. Hamilton, supra note 50.

52. Id.

53. U.S. Const. amend XIV, $\S 1$ (emphasis added).

54. The TRUTH 1, supra note 30. 
by their Creator with certain unalienable rights." ${ }^{55}$ Consequently, a " 'U.S. citizen' is a subject of the federal government, [and subject] to its jurisdiction" but "an 'American Citizen' is a sovereign individual, and the government is subject to him." ${ }_{56}$ Because the Government is subject to the "American Citizen," the Government's courts (the judicial branch) cannot exercise jurisdiction over that person without his or her consent. ${ }^{57}$ Sovereign Citizens believe these core tenets form the building blocks of a legal philosophy that prevents the federal government from exerting control over them.

\section{Divesting from the "legal fiction," oaths, capitalization, and fringe}

Having established two types of citizenship, Sovereign Citizens next seek to divest themselves of their "artificial person"- the being that consented to governance by the federal government. But when did this consent occur? Many believe that the fact that some birth certificates feature the birth name in all capital letters ${ }^{58}$ is proof of "the government's attempt to usurp your sovereign status[.]"59 Others assert that the artificial person is created when a social security number is applied for and issued. ${ }^{60}$ In determining whether one has consented and are therefore "contracted" with the government, Sovereign Citizens are directed to look at their birth certificates, check books, social security cards, tax returns, driver's licenses, and other "legal documents." 61

Once a person determines that a contract has unwittingly been made with the government, Sovereign Citizens believe they can reclaim their "sovereign status," but only by separating oneself "from every benefit offered by the federal government as an inducement to contract." 62 To do so,

55. Id. (citing The Declaration of Independence).

56. Id.

57. Id. ("[N]o court has jurisdiction over him, without his permission.").

58. Id. ("When an artificial person is named (such as a corporation), proper English grammar says that the name will be spelled in all capital letters. So if your name is Joseph John Smith, the spelling indicates that you are a real live flesh and blood natural human (natural person). But if you spell your name in all capitals, JOSEPH JOHN SMITH, then that indicates that you are an artificial entity (person).").

59. Id.

60. Id. ("When you applied for Social Security, this artificial person U.S. citizen was created. Unknowingly, you contracted to be an artificial corporate person, not realizing that you created a new government employee."); Francis X. Sullivan, The Usurping Octopus of Jurisdictional Authority: The Legal Theories of the Sovereign Citizen Movement, 1999 WIS. L. Rev. 785, 802 (1999).

61. The TRUTH 1, supra note 30.

62. Sullivan, supra note 60 , at 809 . 
they must first revoke their birth certificate ${ }^{63}$ by sending various notices and declarations to different government agencies. ${ }^{64}$ A Sovereign Citizen also

[c]annot have a valid Social Security Number, a "resident" State driver's license, a motor vehicle registered in your name, a bank account in a federally insured bank, or any other known "contract implied in fact" that would place you in this "Federal area" and thus within the territorial jurisdiction of the municipal laws of Congress. ${ }^{65}$

Simply revoking the contract, however, is insufficient. Sovereign Citizens are often called into court to account for failing to pay taxes, driving without a license, or other infractions. At this point, Sovereign Citizens believe they must continue to deny jurisdiction; otherwise they may unwittingly accede to the government's authority and enter into another contract. ${ }^{66}$ To avoid this problem, Sovereign Citizens recommend staying out of courts altogether when charged with a crime or civil infraction. Because "American Citizen's have no standing in court," any Sovereign Citizen will necessarily be deemed an "artificial person" when they appear for proceedings. ${ }^{67}$

If one cannot avoid going to court, then Sovereign Citizens believe that there are other means to challenge the validity of the tribunal. First, a Sovereign Citizen should refuse to identify him or herself in court. ${ }^{68} \mathrm{He}$ or she may also point to the language or capitalization of the court documents, asserting that the individual identified in those documents is actually one's renounced legal fiction or "corporate citizen." ${ }^{9}$ Because that entity, as opposed to the "Natural Person," is the subject of the claim, a Sovereign Citizen believes he or she can deny the court's jurisdiction over the physical person present. Accordingly, Sovereign Citizens claim that they are making a "special appearance" only to challenge jurisdiction, or refuse to pass the bar into the courtroom lest they accidently create "joinder."70

63. T. Collins, White Paper on State Citizenship, Libertarian Party of Pennsylvania (Oct. 27, 1997), https://perma.cc/JR6S-BFG6 (this process is called "REVOCATION OF SIGNATURE AND POWER OF ATTORNEY.”).

64. Id. (This process involves sending "[a] notice of intent[; a] declaration of sovereignty[; a]n oath to your state[; a] notice that you are using Federal Reserve Notes under protest[; and a] revocation of signature and power of attorney" to the county recorder's office).

65. Id.

66. Think, by way of analogy, to a defendant acceding to a court's personal jurisdiction by appearing and participating in the litigation.

67. The TRUTH About Court Rooms! Stay Out!, U.S.A. The Republic (Mar. 4, 2012), https://per ma.cc/H6JB-HMLA [hereinafter The TRUTH 2] (Sovereign Citizens also believe that "only a U.S. citizen [aka the 'artificial person'] has standing in today's courts").

68. The Anti-Government Movement Guidebook, The Nat'L Ctr. for State Cт. (1999), https:// perma.cc/ T5NJ-VXFY [hereinafter NCSC Guidebook].

69. Evans, supra note 34, at 1372.

70. Weir, supra note 34 , at 832 . 
When charged with a crime, Sovereign Citizens may ask for the government to present the aggrieved party. ${ }^{71}$ For regulatory crimes such as tax fraud or speeding, there will be no aggrieved party to present. As such, the Sovereign Citizen will contend that the court has no jurisdiction because only a natural person can be the victim of crimes and only an artificial person is subject to statutory law. ${ }^{72}$ Without an aggrieved party, the natural person cannot have committed a crime and the case should be dismissed.

Furthermore, the Sovereign Citizen may challenge the judge's position in the court by asking about his or her "oath." One site suggests that one could "[a]sk the judge if he has taken an oath to uphold and defend the constitution [because] he has to say yes," and then the judge is put on notice that he or she is dealing with a Natural Person with inalienable rights. ${ }^{73}$ If the judge refuses to affirm his or her oath (to the individual's satisfaction), the Sovereign Citizen can move to dismiss for lack of jurisdiction because that refusal secretly means the court is not an Article III court at all. ${ }^{74}$

Lastly, Sovereign Citizens often challenge the authority or jurisdiction of a court based on the type of American flag present. This argument is based on the belief that the Constitution only contemplates three forms of law: "common law, equity (contract law) and Admiralty law."75 While Sovereign Citizens believe they are governed under common law (also known as "God's Law"), admiralty law is actually the "King's Law" and subjects an unwitting party to the federal government's jurisdiction. ${ }^{76}$ So why does the type of flag matter? According to Sovereign Citizens, "[f]ederal territorial law is evidenced by the Executive Branch's Admiralty flag (a federal flag with a gold or yellow fringe on it) . . ."77 This admiralty flag, with its gold fringe, is evidence that the federal government declared martial law

71. Is There a Right to Travel Without a Driver's License in the United States?, PSEUdolaw (Oct. 8, 2017), https://perma.cc/6Z3Y-FX47.

72. M.R. Hamilton, Always Challenge Jurisdiction, AFreeCountry.com (Apr. 25, 2014), https:// perma.cc/L8NB-LEJF ("A crime is only committed when one of the [Natural Persons] 'commits' a crime against another one of the [Natural Persons]. A crime is not committed when a statute has been 'violated' by a [Natural Person], because statutes do not apply to [Natural People], they only apply to ['artificial persons'] and other fictitious entities, such as licensed companies.").

73. Notice of Acceptance of Constitutions and of Oath of Office, Instructions for Use of the Notice of Acceptance of Constitutions and of Oath of Office, FreEdOM-SCHOOL.COM, https://perma.cc/6HLLUR2R [hereinafter Instructions] ("If you ask the judge if he intends to conduct his duties in compliance with that oath, what can he possibly say but yes? The judge knows if the court is an Article III court, but he is hoping you will not understand this or how to force him to comply with his oath of office."); see also OR Judge Refuses Constitutional Oath-Arrests Challenging Citizens, Rense.com (Feb. 21, 2002), https://perma.cc/XN5Y-T2ZS.

74. Instructions, supra note 73 .

75. Treason in Government! Admiralty on Land! Where's the Water?, BAREFOOTSWORLD.ORG (Apr. 27, 1997), https://perma.cc/9STV-C7K3 [hereinafter Treason].

76. Treason, supra note 73 ("When you walk into a court and see this flag you are put on notice that you are in a Admiralty Court and that the king is in control.").

77. Collins, supra note 63. 
and sought to establish courts with complete control. ${ }^{78}$ Accordingly, Sovereign Citizens argue that "any action taken under the yellow-fringed "American flag of war' is a deprivation of due process" and that the court has unlawfully taken away your constitutional or inalienable sovereign rights. ${ }^{79}$ By denying these rights and subjecting a natural person to an improperly formed military tribunal, Sovereign Citizens believe the court has no real jurisdiction over them.

\section{B. The Redemption Scheme}

Closely related to the Natural Persons theory is the Redemption Scheme, which expands upon the notion of a government-created "strawman" that can be used to satisfy debts and avoid paying federal income taxes. ${ }^{80}$ Sovereign Citizens believe that when the U.S. Government went off the gold standard in 1933, it pledged the future earnings of its citizens to support the value of its currency. ${ }^{81}$ By subsequently removing oneself as surety for the strawman (otherwise referred to as an "artificial person"), the Sovereign Citizen believes an individual can control the strawman and access the "Treasury Direct Account" that holds all the borrowed collateral. ${ }^{82}$

\section{The fall of the Gold Standard and the rise of the Redemption Scheme}

According to Sovereign Citizens, the beginning of the financial ruin of the United States Government began in 1913 when Congress passed the Federal Reserve Act. ${ }^{83}$ That Act created and established the Federal Reserve System, which created a central bank that could, among other things, issue Federal Reserve Notes (U.S. dollars). ${ }^{84}$ Sovereign Citizens believe that in 1933 ,

[t]he International Bankers served Notice of [debt and insolvency] on the government. Between January and July of 1933 the Roosevelt Administration and Congress responded. Exactly how all this was orchestrated is too

78. The TRUTH 2, supra note 67; see also Treason, supra note 73 (citing "Pursuant to U.S.C. Chapter 1, 2, and 3; Executive Order No. 10834, August 21, 1959, 24 F.R. 6865, a military flag is a flag that resembles the regular flag of the United States, except that it has a YELLOW FRINGE, bordered on three sides. The President of the United states designates this deviation from the regular flag, by executive order, and in his capacity as COMMANDER-IN-CHIEF of the Armed forces.").

79. Sullivan, supra note 60 , at 805 .

80. See M.R. Hamilton, Are You required to Pay a Tax on Your Income?, AFreECountry.COM (Mar. 29, 2014), https://perma.cc/Y3TA-6UHN.

81. The Sovereigns, supra note 23.

82. Meeting Your Strawman, LeGalUCC.com, https://perma.cc/3W34-7TW9.

83. J.M. Berger, Without Prejudice: What Sovereign Citizens Believe, George Washington Univ. Program on Extremism (June 2016), https://perma.cc/9RXF-9UFX; see also Meads, 2012 ABQB at 530. 84. Berger, supra note 83.

$\mathbf{R}$

$\mathbf{R}$

$\mathbf{R}$

$\mathbf{R}$ 
lengthy to be addressed here, but this fact is clear -since then the birth or naturalization record for every U.S. Citizen is on file in the official records in Washington, D.C. and the property and assets of every living U.S. Citizen is pledged as collateral for the National Debt. ${ }^{85}$

The Federal Reserve, a "private corporation," then began issuing private commercial debt instruments known as "Federal Reserve Notes." 86 In order to meet the demand for ever growing federal spending, the government assigned all U.S. born citizens - present and future-as collateral. ${ }^{87}$

The government achieved, and allegedly continues to achieve, this goal by registering all newborn babies, through their "Certificate of Live Birth" and social security numbers, in Washington, D.C. ${ }^{88}$ A "bond" is then taken out by the Department of the Treasury and held in a "Treasury Direct Account." 89 Some Sovereign Citizens believe that account contains anywhere from $\$ 650,000,{ }^{90}$ to $\$ 1,000,000,{ }^{91}$ to $\$ 20,000,000,{ }^{92}$ per person.

While the pre-divested or pre-redeemed person acts as a beneficiary and surety for the bond, the "redeemed" person can make use of it by controlling the strawman. Prior to making use of this bond, one must generally complete the divesting process previously described. ${ }^{93}$ Otherwise, an individual would be forced to work off the U.S. Government's debt as a surety to one's artificial person and a wage-slave, because "any time you use [Federal Reserve Notes], you are dealing with the property of a corporation, a legal fiction in law. And a fiction can only deal with another artificial person."94

2. Tactics used to free money from the "Strawman" or "When in commerce do as commerce does, use the Uniform Commercial Code"

Through "redemption," a process that looks similar to divestment from an artificial person, the Sovereign Citizen can separate himself from the fictitious strawman and make use of the funds that are located in the Trea-

85. Barton A. Buhtz, An Investigative Report, FAMGUARDIAN.org (May 26, 2003), http://famguardian.org/ subjects/MoneyBanking/UCC/InvestigativeReportUCC.pdf; The TRUTH About the United States Government Bankruptcy! and National Emergencies!, U.S.A. The Republic (Mar, 4, 2012), https://perma.cc/G4QV-P8T6 [hereinafter The TRUTH 3].

86. The TRUTH 3, supra note 85.

87. Id.

88. Buhtz, supra note 85 (Evidence of this scheme is purportedly displayed on "the Certificate of Live Birth," where "a bond \# is stamped on the back").

89. Sovereign Citizen Movement: Extremists Claim to be "Beyond the Law", supra note 22.

90. Buhtz, supra note 85 .

91. Meeting Your Strawman, supra note 82.

92. The Sovereigns, supra note 23.

93. See Mallek, supra note 13.

94. The TRUTH 3, supra note 85. 
sury Direct Account. ${ }^{95}$ The redeemed Sovereign Citizen will also then be "the controller and creditor with the highest lien hold interest in the straw man." 96 As for the process, it begins with the UCC, which Sovereign Citizens believe "is legislated (Administrative Law) that codifies the rules for all commercial transactions between countries, states and individuals." 97 Because "the courts acknowledge they do not have the authority or jurisdiction to amend, alter or nullify any of the Articles of the UCC," invocation of the Code is believed to be unassailable. ${ }^{98}$

First, the Sovereign Citizen must submit a copy of UCC Financing Statement ("UCC-1"), in hard copy, with an original signature, presented via certified or registered mail, to both the state and the Secretary of the Treasury. ${ }^{99}$ Once filed, it becomes "a legal document of public record identifying the filer as the Secured Party[,]" presumably to the strawman. Thereafter, Sovereign Citizens believe that "no court can lawfully rule on the fact or existence of the filing itself [because that] filing is a legal fact[,]" and "there is a secured, vested interest therein holding a superior claim and all other parties at interest who file thereafter must acknowledge, accept and respect the Secured Party's superior and prior position." 100 Adjustments to the original document can be made by filing an amendment under UCC-3, which permits amendments to a UCC-1 Financing Statement. ${ }^{101}$

Alternatively, some Sovereign Citizens believe that one "must send a nonnegotiable (private) 'Charge Back' \& a nonnegotiable 'Bill of Exchange' to the United States Secretary of Treasury, along with a copy of [your] birth certificate, the evidence, the [Manufacturer's Certificate of Origin] of the straw man." 102 By doing this, one discharges his or her "portion of the public debt, releasing the real man, from the debts, liabilities $\&$ obligations of the straw man," 103 which grants that person access to the funds as the Secured Party.

Once these documents are filed, one can also use "Bills of Exchange" or other documents to redeem funds or pay for goods. A bill of exchange purportedly accesses the Treasury Direct Account, which they believe contains the balance of the strawman's bond under 26 U.S.C.

95. Sovereign Citizen Movement: Extremists Claim to be "Beyond the Law", supra note 22; The Sovereigns, supra note 23.

96. Meeting Your Strawman, supra note 82 ("[The redeemed person] does not own the straw man but he controls the straw man by the primary lien hold interest.”).

97. Buhtz, supra note 85 .

98. Id.

99. Id. (UCC-1 "details a Secured Party's status in any commercial transaction according to the Articles of the UCC as well as various section[s] of the United States Code dealing with 'Property'"). 100. Id.

101. Id.

102. Meeting Your Strawman, supra note 82 .

103. Id. 
$\S 163(\mathrm{~h})(3)(\mathrm{B})(\mathrm{ii}) .{ }^{104}$ All a Sovereign Citizen needs to do is write a Bill of Exchange for the exact amount owed and send it to the creditor and the Treasury Department; in theory, the Treasury Department will pay the amount out of the Treasury Direct Account. ${ }^{105}$ Alternatively, it can be referred to as a "Charge Back Notice," which should be sent to both the creditor and the Treasury Department. ${ }^{106}$ When a claim for back taxes "is made by the IRS, a federal or state taxing agency," a Sovereign Citizen need only stamp "Accepted For Value" and mail it "to the Secretary of the Treasury for discharge." 107 Sovereign Citizens believe the authority for this action is documented in House Joint Resolution 192 and the Supreme Court's holding in Guaranty Trust Co. v. Henwood. ${ }^{108}$ By and through this process, Sovereign Citizens believe they have unlocked the key to reclaim their wealth from the government. ${ }^{109}$

\section{A Sovereign Citizen's constitutional "right to travel"}

The most common type of Sovereign Citizen claim encountered by local and state police, as well as federal border patrol agents, is the "right to travel." ${ }^{110}$ Citing the Constitution, ${ }^{111}$ Supreme Court cases, and a plethora of other sources, Sovereign Citizens believe they are not required to have driver's licenses, license plates, vehicle registration, or to stop at border or sobriety checkpoints. ${ }^{112}$ Similar to other claims, Sovereign Citizens discussing the "right to travel" place special emphasis on the words being used. They differentiate between a driver and a traveler; an automobile and a motor vehicle; commercial and non-commercial; and public versus private

104. Id.

105. Buhtz, supra note 85 .

106. Sovereign Citizen Movement: Extremists Claim to be “Beyond the Law”, supra note 22.

107. Buhtz, supra note 85.

108. 307 U.S. 247 (1939); Buhtz, supra note 85.

109. Although the core Redemption concepts have remained consistent, there are numerous variations on the basic scheme created by new "gurus" regularly. See Gold Shield Alliance, Freedom in Action GoldShieldAlliance, https://perma.cc/9R2N-UTMT; Cyber Museum of Scams \& Frauds, Quatloos, available at http://www.quatloos.com/Q-Forum/viewtopic.php? $\mathrm{f}=49 \& \mathrm{t}=11506$ (last visited Mar. 2, 2019); Fogbow Falsehoods Unchallenged Only Fester and Grow, THE FoG Bow, https://perma .cc/XW6H-9F9C.

110. See, e.g., Not Personal, Sovereign Citizen 'Right To Travel' Fails in Challenge to Court's Jurisdiction, YouTube (Sept. 20, 2017), available at https://www.youtube.com/watch?v=BqH1rHDSBO8 (last visited Mar. 2, 2019). Sovereign Citizens often video record their interactions with police and courts, especially when challenging driving laws.

111. Although the "freedom to travel" is most often invoked in state courts, the federal Constitution is the document most often relied upon. State law, however, may also provide ample refutation of many state-related sovereign citizen claims. Pamela B. Loginsky, Freemen: Armageddon's Prophets of Hate and Terror, A Washington Association of Prosecuting Attorneys (Jan. 25, 1999), https://perma .cc/QZ7S-VEQL.

112. Sullivan, supra note 60 , at 799 . 
conveyances. ${ }^{113}$ Once a Sovereign Citizen claims that he or she is merely a traveler or traveling, he or she then uses federal and state cases to support the "right to travel." Sovereign Citizens also believe the right to travel constitutes a complete bar on government interference with travel in the absence of probable cause or evidence that a victim has been harmed. ${ }^{114}$

\section{Specific language and use of words}

First, Sovereign Citizens claim that " 'to drive' is to go on the roads by a motorized conveyance doing business or being engaged in commerce, and it is a privilege. 'To travel,' on the other hand, is a right, and no legislation can be passed to strip you of your fundamental, inherent rights." 115 Why does this matter? Because "[t]o state you are 'driving' is to unwittingly place yourself in admiralty or commercial jurisdiction[, and as] a sovereign being, you never need surrender your rights and exchange them for privileges."116

Where these allegedly binding definitions come from is a varied and often perplexing matter. Looking to the terms "travel" and "traveler," Sovereign Citizens believe they "refer[] to one who uses a conveyance to go from one place to another, and include[s] all those who use the highways as a matter of Right" because "the phrase "for hire' never occurs." ${ }_{117}$ Conversely, the term "driver" is defined as "[o]ne employed in conducting a coach, carriage, wagon, or other vehicle[,]" and therefore "[it] should be self-evident that this individual could not be 'traveling' on a journey, but is using the road as a place of business." 118

Likewise, the terms "automobile" and "motor vehicle" denote special meaning. "The word 'automobile' connotes a pleasure vehicle designed for the transportation of persons on highways," and "is private property in use for private purposes." 119 Whereas "motor vehicle" is defined in 18 U.S.C. $\S 31$ as "every description of carriage or other contrivance propelled or drawn by mechanical power and used for commercial purposes on the highways in the transportation of passengers, passengers and property, or property or cargo." Looking to these definitions, Sovereign Citizens deduce that

113. Id.

114. Id. at 799-00.

115. Makia Freeman, How to Drive Without a License, The Freedom Articles (Aug. 7, 2013), https://perma.cc/RZA6-UHKA.

116. $I d$.

117. How You Lost It! Driver Licensing vs. the Right to Travel, U.S.A The RePubLIC, https://perma .cc/4829-PF4A (last visited May 11, 2018) [hereinafter How You Lost It!] (citing 25 AM. JUR. 1st Highways $\$ 427$ (1936); Lockett v. State, 47 Ala. 42 (1872)); Traveler, Bouvier's Law Dictionary (8th ed., 1914); Travel, Century Dictionary (1st ed., 1889)).

118. Id. (citing Driver, Bouvier's Law Dictionary (8th ed. 1914)).

119. Id. (quoting American Mut. Liab. Ins. Co. v. Chaput, 60 A.2d 118, 120 (N.H. 1948). 
"[c]learly, an automobile is private property in use for private purposes, while a motor vehicle is a machine which may be used upon the highways for trade, commerce, or hire." ${ }^{120}$ Moreover, "one who uses the road in the ordinary course of life and business for the purpose of travel and transportation is a traveler." 121

As a non-commercial traveler using a private conveyance such as an automobile, Sovereign Citizens believe that one should not be required to obtain a license. Pointing to Black's Law Dictionary, which defines "license" as "[t]he permission by competent authority to do an act which, without such permission, would be illegal, a trespass, a tort, or otherwise not allowable," 122 a Sovereign Citizen refutes the idea of needing a license to drive. "A license is permission from the government to do something, that, without the license, would be illegal," and traveling is not illegal. ${ }^{123}$ Under this rationale, one cannot be required to have a license to travel because traveling is a constitutional right.

\section{The "right" to travel}

Beginning with this "correct" terminology, Sovereign Citizens point to a surplus of Supreme Court and state court precedents that recognize a "right to travel." The four most common cases and quotes, reproduced across most Sovereign Citizen forums, are: ${ }^{124}$

(1) "The use of the highway for the purpose of travel and transportation is not a mere privilege, but a common fundamental right of which the public and individuals cannot rightfully be deprived." Chicago Motor Coach v. Chicago, 169 NE 221.125

(2) "The right of the citizen to travel upon the public highways and to transport his property thereon, either by carriage or by automobile, is not a mere privilege which a city may prohibit or permit at will, but a common law right which he has under the right to life, liberty, and the pursuit of happiness." Thompson v. Smith, 154 SE 579. ${ }^{126}$

120. Id. (quoting American Mut. Liab. Ins. Co. v. Chaput, 60 A.2d 118, 120 (N.H. 1948).

121. $I d$.

122. License, Black's Law Dictionary (6th ed., 1990).

123. The TRUTH About Inalienable Rights!, U.S.A. The RePUbLic, https://perma.cc/3JKN-LPV6 (last visited May 11, 2018) [hereinafter The TRUTH 4].

124. In what could be considered psuedolaw irony, these commonly reproduced passages are not accurate to the actual caselaw. See, e.g., Jack McLamb, Despite Actions of Police and Local Courts, Higher Courts Have Ruled That American Citizens Have a Right to Travel Without State Permits, LawFUL PATH (last modified 2014), https://perma.cc/2TRY-35SL; The TRUTH 4, supra note 123; Sovereign Right to Operate a Private Vehicle, THECOUNTRYGUARD.org, https://perma.cc/US53-MPD3 [hereinafter Sovereign Right to Operate].

125. 169 N.E. 22, 28 (Ill. 1929).

126. 154 S.E. 579,583 (Va. 1930 ). 
(3) "The right to travel is a part of the liberty of which the citizen cannot be deprived without due process of law under the Fifth Amendment." Kent v. Dulles, 357 U.S. 116, 125. ${ }^{127}$

(4) "The right to travel is a well-established common right that does not owe its existence to the federal government. It is recognized by the courts as a natural right." Schactman v. Dulles, 96 App DC 287, 225 F2d 938, at 941. ${ }^{128}$

Looking at these cases, Sovereign Citizens believe "[i]t could not be stated more directly or conclusively that citizens of the states have a common law right to travel, without approval or restriction (license), and that this right is protected under the U.S Constitution." 129 Furthermore, as a right that is "fundamental to our existence," Sovereign Citizens believe that the right to travel can never be abrogated or regulated in any way. ${ }^{130}$

\section{The "right" not to be stopped}

At traffic stops and DUI or border patrol checkpoints, Sovereign Citizens will often contest the legality of the state action and recite questions such as "Am I free to go?" or "What is your articulable reason for stopping me?" to any and all questions by the police. ${ }^{131}$ They may refuse to speak whatsoever, simply pressing a piece of paper against the vehicle's window. ${ }^{132}$ This resistance is generally based on one of three notions. First, the "Government-in requiring the people to obtain drivers licenses, and accepting vehicle inspections and DUI/DWI roadblocks without question-is restricting, and therefore violating, the people's common law right to travel." 133 Second, the police may not stop a vehicle or detain an individual absent being able to articulate a reasonable suspicion of a crime being committed. ${ }^{134}$ Third, the government cannot tax individuals for exercising their

127. 357 U.S. 116, 125 (1958).

128. 225 F.2d 938, 941 (D.C. 1955).

129. McLamb, supra note 124

130. Freeman, supra note 115 ("Our right to travel can never be stripped from us; it is as fundamental to our existence as our right to breathe.").

131. See The Freedom Paradox, Crushing A DUI Checkpoint, YouTube (Aug. 25, 2015), available at https://www.youtube.com/watch?=64\&v=7nDiBC28GYs (last visited Mar. 2, 2019); Thomas Sauer, Border Patrol Corruption, YouTube (Nov. 6, 2014), available at https://www.youtube.com/watch?=33 $2 \& \mathrm{v}=\mathrm{yhtDTOHigcg}$ (last visited Mar. 2, 2019).

132. Notice to Checkpoint Agents, FREEDOMSCHOOL.com, https://perma.cc/ESK7-QF39 [hereinafter Notice to Checkpoint Agents].

133. McLamb, supra note 124.

134. Notice to Checkpoint Agents, supra note 132 (citing United States v. Martinez-Fuerte, 428 U.S. 543 (1976)). 
constitutional rights, ${ }^{135}$ and speed limits or checkpoints are "simply an unlawful tax or impost on travel" under Crandall v. Nevada. ${ }^{136}$

\section{A Legal Response}

Most of the Sovereign Citizens' claims and jurisdictional challengesfrom capitalization to oaths-depend on the Natural Persons theory. ${ }^{137}$ Indeed, if the Fourteenth Amendment did not create an "Artificial Person" or an unwitting "contract" with the federal government, then these individuals would be subject to the federal government's jurisdiction. The Redemption Scheme also relies on this distinction in that the Government has allegedly borrowed against and holds money on behalf of a Natural Person's artificial "strawman." 138 Furthermore, by seeking to enforce traffic laws, the Sovereign Citizen believes the Government is executing its contractual rights against the corporate entity of the artificial person. ${ }^{139}$ In rebutting these claims, it is first necessary to establish where a person's constitutional rights are found, who decides what statutes and the Constitution means, and what documents or sources have binding legal effect. While some of the following is fairly academic for trained lawyers, Sovereign Citizens lack the foundational precepts of the American legal system and Constitution. To rebut the movement's substantive constitutional claims, lawyers will need to explain the fundamentals to Sovereign Citizens before we can reverse the movement's growth.

\section{A. Dude, where are my rights?}

Sovereign Citizens often cite the U.S. Constitution, the UCC, the Magna Carta, ${ }^{140}$ the Articles of Confederation, ${ }^{141}$ and numerous other quasi-legal document to support their assertions. Although authoritative sounding, the true basis for a citizen's constitutional rights is found in the Constitution itself. The U.S. Supreme Court is the only legal body that can interpret and give legal effect to the Constitution. Accordingly, Sovereign

135. How You Lost It!', supra note 117 ("The power to tax is the power to destroy, and if the state is given the power to destroy Rights through taxation, the framers of the Constitution wrote that document in vain.").

136. Sovereign Right to Operate, supra note 124 (citing Crandall v. Nevada, 73 U.S. 35 (1868)).

137. See supra Part II(A).

138. See supra Part II(B).

139. See supra Part II(C).

140. See Kennedy v. Law Sch. Admissions Council, Inc., No. CV 18-1316-RGA, 2018 WL 6188781, at*1 (D. Del. Nov. 27, 2018); see also Kevin Underhill, Rejected Applicant Sues Law Schools for Violating Magna Carta, Lowering THE BAR (Sept. 19, 2018), https://perma.cc/NXH6-NZLX.

141. People or Citizen, Which One Are You?, 1215.org, https://perma.cc/KTU2-8YEM. 
Citizens' citations to-and reliance on-dictionaries, state court opinions, specific capitalization, or state records are misplaced and unavailing.

\section{The U.S. Constitution and constitutional rights}

On July 4, 1776, the Second Continental Congress adopted the United States Declaration of Independence. As stated by the Declaration's preamble, all men "are endowed by their Creator with certain unalienable Rights, that among these are Life, Liberty and the pursuit of Happiness."142 "[T]o secure these rights, Governments are instituted among Men, [and they] deriv[e] their just powers from the consent of the governed[.]" 143 These aspirational statements do not provide substantive rights nor do they have "have the force of organic law." 144 In the Declaration's final section, however, it proclaimed that the United States owed no allegiance or loyalty to the British crown and were no longer subject to its laws. ${ }^{145}$ This section alone, arguably, is the only statement in the Declaration that does more than provide a statement of facts or grievances; it provides the justification for the American Revolution. Effectively, other than establishing that the United States "of Right ought to be Free and Independent States," the Declaration has no binding or legal force. ${ }^{146}$

The Articles of Confederation, which first established a federal government in 1781, likely lost their binding force with the ratification required under Article VII of the proposed Constitution. ${ }^{147}$ Under Article VI, Clause 2, of the Constitution, also known as the "Supremacy Clause," only the "Constitution, and the Laws of the United States which shall be made in Pursuance thereof; and all Treaties made, or which shall be made, under the Authority of the United States, shall be the supreme Law of the Land[.]"148 Accordingly, members of the federal government who swear oaths to the

142. The Declaration of Independence pmbl. (1776).

143. The Declaration of Independence pmbl. (1776).

144. Cotting v. Godard, 183 U.S. 79, 107 (1901) (stating "[w]hile such declaration of principles may not have the force of organic law, or be made the basis of judicial decision as to the limits of right and duty, and while in all cases reference must be had to the organic law of the nation for such limits, yet the latter is but the body and the letter of which the former is the thought and the spirit, and it is always safe to read the letter of the Constitution in the spirit of the Declaration of Independence" (quoting Yick Wo v. Hopkins, 118 U. S. 356, 369 (1886))).

145. The Declaration of Independence pmbl. (1776).

146. Troxel v. Granville, 530 U.S. 57, 91 (2000) (Scalia, J., dissenting) ("The Declaration of Independence, however, is not a legal prescription conferring powers upon the courts.").

147. Scott v. Jones, 46 U.S. 343, 360 (1847) ("[I]t pleased the whole people of the United States to abolish their government, and to abrogate the old articles of confederation. A new constitution was adopted, an entirely new form of government was established, which took the place of the old one."); Vasan Kesavan, When Did the Articles of Confederation Cease to Be Law, 78 Notre Dame L. Rev. 35 , 49-50 (2002).

148. U.S. Const. art. VI, cl. 2. 
Constitution, as well as "the Judges in every State," are bound by this "supreme Law." 149 In sum, the Constitution-and statutes or treaties lawfully made under the Constitution - are the binding law that citizens are protected by and must follow.

\section{Interpreting the Constitution and case law}

In rebutting Sovereign Citizen arguments, however, it is necessary to establish what is and what is not binding law under the Constitution-as well as who has the power to decide those questions. Academic or elementary as it may be to lawyers, Sovereign Citizens routinely use as "evidence" non-constitutional and non-binding authorities. Under Article III, Section 2, the power of the federal judiciary is "extend[ed] to all cases, in law and equity, arising under this Constitution, the laws of the United States, and treaties made, or which shall be made, under their authority[.]"150 In Marbury v. Madison, ${ }^{151}$ the Supreme Court established its role in reviewing the laws and the Constitution:

[I]f a law be in opposition to the constitution; if both the law and the constitution apply to a particular case, so that the court must either decide that case conformably to the law, disregarding the constitution; or conformably to the constitution, disregarding the law; the court must determine which of these conflicting rules governs the case. ${ }^{152}$

This judicial power of constitutional and federal statutory review, which is "vested in one supreme Court, and in such inferior Courts as the Congress may from time to time ordain and establish," 153 has also necessarily been extended to review state civil ${ }^{154}$ and criminal ${ }^{155}$ cases that implicate the Constitution or federal law. The authority of the judiciary, stemming from Article III, Section 2, of the Constitution, applies:

[t]o all Cases affecting Ambassadors, other public Ministers and Consuls;to all Cases of admiralty and maritime Jurisdiction;- to Controversies to which the United States shall be a Party; - to Controversies between two or more States;- - between a State and Citizens of another State;- - between Citizens of different States;-between Citizens of the same State claiming Lands under Grants of different States, and between a State, or the Citizens thereof, and foreign States, Citizens or Subjects."156

149. U.S. Const. art. VI, cl. 2.

150. U.S. Const, art. III, $\S 2$.

151. 5 U.S. (1 Cranch) 137 (1803).

152. Marbury v. Madison, 5 U.S. (1 Cranch) 137, 178 (1803) (emphasis added).

153. U.S. Const. art. III, § 1.

154. Martin v. Hunter's Lessee, 14 U.S. (1 Wheat.) 304 (1816).

155. Cohens v. Virginia, 19 U.S. (6 Wheat.) 264 (1821).

156. U.S. Const, art. III, $\S 2$. 
Notably, the power extends to all cases and controversies enumerated including admiralty claims, belying a commonly held Sovereign Citizen belief that the federal courts sit in admiralty only. ${ }^{157}$ Additionally, the distinction between "common law, equity (contract law) and Admiralty law" is not jurisdictional, but rather affects the form of relief provided by the courts. And as Article III, Section 2, makes clear, "[t]he judicial power shall extend to all cases, in law and equity." 158 In short, the United States Supreme Court is the final arbiter of constitutional interpretation and application to state and federal laws, in every case.

More specifically, the only portion of a Supreme Court opinion that is legally binding is the judicial holding - i.e., those parts of a court's opinion that were necessary for the decision. The Supreme Court-and common law rules of interpretation-mandate that words and phrases should be analyzed and applied in light of their context, not in isolation. ${ }^{159}$ In Hynes $v$. Grimes Packing Company, ${ }^{160}$ the Court admonished a party that attempted to narrowly define a statutory term by cherry-picking favorable language. Similarly, pulling distinct phrases from judicial opinions ${ }^{161}$ or contracts, ${ }^{162}$ without consideration of the context, can be misleading. This is especially true for individuals persuaded by Sovereign Citizens' oft-quoted language, which is effectively given "a talismanic significance."163

\section{Fringe on the flag}

Relatedly, the flag in a courtroom does not "signal" that a court is sitting in admiralty jurisdiction or somehow limit a court's authority over a defendant. 4 U.S.C $§ 1$ states that " $[t]$ he flag of the United States shall be thirteen horizontal stripes, alternate red and white; and the union of the flag shall be forty-eight stars, white in a blue field." 164 In 1925, Attorney Gen-

157. Not Personal, Sovereign Citizen Freeman in Court Utterly Fails with Judge - Default Issued, YouTube (Jan. 19, 2016), available at https://www.youtube.com/watch? $\mathrm{v}=\mathrm{jBK}-\mathrm{DMDlzM} 4 \&$ feature= youtu.be (last visited Mar. 2, 2019).

158. U.S. Const. art. III, $\S 2$; see also Federal Rules of Civil Procedure Merge Equity and Common Law, Fed. Judicial Center, https://perma.cc/EM9F-X2GR (discussing the FRCP's merger of equity and common law).

159. United States v. American Trucking Ass'n, Inc., 310 U.S. 534, $542-43$ (1940).

160. 337 U.S. 86, 115-16 (1949) (“[O]ne may not fully comprehend the statute's scope by extracting from it a single phrase, such as 'public lands' and getting the phrase's meaning from the dictionary or even from dissimilar statutes.").

161. Alexander v. Sandoval, 532 U.S. 275, 282 (2001) ("[T]his Court is bound by holdings, not language.").

162. Macdonald v. Winfield Corp., 191 F.2d 32, 35 (3d Cir. 1951) ("[N]o principle of contract law requires or even permits us to take the word out of context.").

163. Illinois ex rel. Hartigan v. Panhandle E. Pipe Line Co., 852 F.2d 891, 893 (7th Cir. 1988), abrogated on other grounds by Kansas v. UtiliCorp United, Inc., 497 U.S. 199 (1990).

164. The Flag of the United States, Exec. Order No. 10834, 24 Fed. Reg. 6865 (1959-1953) (providing that the flag shall have 50 stars). 
eral John G. Sargent addressed the use of fringe on the flag pursuant to Army Regulations, No. 260-10.165 In finding that the "matter is one of those over which Congress may exercise control if it will," 166 the absence of a statute meant "that the question of a fringe may be determined by the President as Commander in Chief." 167 The last executive order on the matter, Executive Order No. 10834, "signed by President Eisenhower, himself a military man, did not address this issue." 168 Ultimately, no relief can be afforded based on fringe around the flag as "fringe is not considered to be a part of the flag, and it is without heraldic significance."169

\section{Capitalization, dictionaries, and special words}

Despite the importance attributed by Sovereign Citizens to the specific capitalization of words or names, these arguments are also without merit. ${ }^{170}$ Although the capitalization used in the Declaration of Independence and Constitution appear unique to present-day readers, the drafters used a thencommon stylistic choice to capitalize nouns, likely owed to Germanic language heritage. ${ }^{171}$ Additionally, "[c]aptioning court documents with all capital letters complies with Fed. R. Civ. P. 10(a)"172 and "[t]he use of all capital letters in the caption of court documents is a typographical convention without legal significance." 173 Ultimately, capitalization is irrelevant to establishing substantive rights or proving some hidden meaning in an indictment or legal pleading.

Sovereign Citizens also make the mistake of relying on excerpts of cases, dictionary definitions, and isolated statutes to "prove" their claims. As previously discussed, the Supreme Court alone has the power to definitively interpret and define the terms that appear in the Constitution or federal statutes. For that reason, Sovereign Citizens' reliance on state court

165. Nat'1 Flag of U.S., 34 Op. Att'y Gen. 483, 485 (1925).

166. Id. at 487.

167. Id. at 486 .

168. McCann v. Greenway, 952 F. Supp. 647, 650-51 (W.D. Mo. 1997) (citing Exec. Order No. 10834, 24 Fed. Reg. 6865 (1959-1953)).

169. Nat'l Flag of U.S., supra note 165, at 485.

170. One example is the "Republic for the united States of America," a Sovereign Citizen alternative government that claimed it was the real United States government based on the lower-case U in "united States" used in the Declaration of Independence. See Self-Proclaimed President of Sovereign Citizen Group Sentenced to Federal Prison for Promoting Tax Fraud Scheme, Federal Bureau of InvestigaTION (July 31, 2013), https://perma.cc/DTV6-8E8B.

171. Judith Thurman, In Defense of Cursive, New YORKER (July 5, 2012), https://perma.cc/4PKZ$38 \mathrm{FH}$.

172. Adams v. City of Marshall, No. 4:05-CV-62, 2005 WL 2739029, at*1 (W.D. Mich. Oct. 24, 2005).

173. City of Marshall, 2005 WL 2739029, at *1 (quoting United States v. Heijnen, 375 F. Supp. 2d 1229, 1231 (D. N.M., 2005)). 
opinions to support their various constitutional claims is fundamentally flawed. Nor may individuals rely on dictionary definitions to determine the precise meaning of words that appear in the Constitution. Even though venerated publications such as Black's Law Dictionary may be helpful or illuminating, ${ }^{174}$ they are not binding legal authority and cannot be relied upon to establish one's rights. ${ }^{175}$

\section{Birth certificates, social security numbers, and the Uniform Commercial Code}

Lastly, social security numbers, birth certificates, and invocations of the UCC do not constitute a contract with the government, nor do they represent tacit government acknowledgment of some artificial person. Social security numbers and birth certificates are merely records designed to track births and citizens, and the UCC is inapplicable to the federal government and without legal authority unless codified by a state:

Birth certificates are legal documents issued by the state in which a birth occurs, and social security numbers are a form of identification issued by the Social Security Administration, an agency of the federal government. Neither birth certificates nor social security numbers recognize or impose contractual rights, obligations, or duties. ${ }^{176}$

Additionally, birth certificates are non-transferable items and do not qualify as commercial paper under the oft-cited UCC § 3-104, nor may a person "legally profit from the sale of birth certificates [as] such documents hold no commercial value." 177 Pointedly, 42 U.S.C. § 405 grants the Commissioner of Social Security the statutory authority to issue social security numbers, requiring "applicants for social security account numbers" to provide the Commissioner with evidence of "age, citizenship, or alien status, and true identity[.]" 178 If social security numbers were actually a grant or recognition of an artificial citizenship conferred by the government, there would be no requirement to provide evidence of any additional facts.

The UCC, which Sovereign Citizens rely on to establish substantive rights and to divest themselves of their "artificial" U.S. citizenship, deals primarily with transactions involving personal property (movable property), and not real property (immovable property). The UCC is not itself law. ${ }^{179}$

174. See Smith v. United States, 508 U.S. 223 (1993).

175. Alabama Educ. Ass'n v. State Superintendent of Educ., 746 F.3d 1135, 1150 n.12 (11th Cir. 2014); King v. St. Vincent's Hosp., 502 U.S. 215, 221 (11th Cir. 1991).

176. Gravatt v. United States, 100 Fed. Cl. 279, 286 (2011).

177. Palmer v. Everson, No. C-2-08-466, 2008 WL 5109195, at*3 (S.D. Ohio Dec. 1, 2008).

178. 42 U.S.C. $\S 405$ (c)(2)(B)(i)-(ii) (2018).

179. Gilbert v. Monaco Coach Corp., 352 F. Supp. 2d 1323, 1329 (N.D. Ga. 2004) ("The UCC, itself, is not the law of any state, nor is it federal law.”); Calo-Rivera v. Banco Popular De Puerto Rico, No. 05-1832 CCC, 2006 WL 1514377, at *5 (D.P.R. May 31, 2006) (quoting U.C.C. Preface (2005) 
Instead, it is proposed law-created as a joint project of the National Conference of Commissioners on Uniform State Laws and the American Law Institute (both private organizations) - that can be adopted by states. ${ }^{180}$ Once enacted, the UCC is codified into a state's code of statutes. "[T]he U.S. Government, as the sovereign, is not bound by such State statutes as the UCC." 181 And although unrelated to the Redemption Scheme generally, the UCC also cannot provide a basis for challenges to federal incarceration. ${ }^{182}$

\section{B. Citizenship and jurisdiction}

I turn now to the Sovereign Citizens claims regarding citizenship and jurisdiction. The Citizenship Clause and Privileges or Immunities Clause of the Fourteenth Amendment, as well as other federal statutes, provide the government with jurisdiction to prosecute citizens and non-citizens living in the United States.

\section{Citizenship Clause}

Section 1, clause 1, of the Fourteenth Amendment, the "Citizenship Clause," states that "All persons born or naturalized in the United States, and subject to the jurisdiction thereof, are citizens of the United States and of the State wherein they reside." In United States v. Wong Kim Ark, ${ }^{183}$ the Supreme Court examined this clause and its implications for children born in the United States to foreign parents. ${ }^{184}$ The Court noted that "it is beyond doubt that, before . . . the adoption of the [Fourteenth Amendment], all white persons, at least, born within the sovereignty of the United States . . . were native-born citizens of the United States." 185

The Citizenship Clause's "main purpose doubtless was . . . to put it beyond doubt that all blacks, as well as whites, born or naturalized within the jurisdiction of the United States, are citizens of the United States."186 "The phrase 'subject to its jurisdiction,", the Court concluded, "was in-

("The Code is not federal law. It is a "comprehensive modernizations of various statutes relating to commercial transactions ...' prepared under the joint sponsorship of the American Law Institute and the National Conference of Commissioner on Uniform State Laws ....”)).

180. For example, Louisiana has only adopted parts of the UCC. R.R. Kyle Ardoin, What is Uniform Commercial Code?, Louisiana Security of State, https://perma.cc/642Z-C47S.

181. Whitesell v. Comm'r, 113 T.C.M. (CCH) 1406 (2017) (citing Burnet v. Harmel, 287 U.S. 103, $110(1932))$.

182. Carter v. Wands, 431 F. App'x 628, 629 (10th Cir. 2011) (mem.) ("Nor does the UCC provide a basis to challenge the conditions of his imprisonment").

183. 169 U.S. 649 (1898).

184. Id. at $674-75$.

185. Id.

186. Id. 
tended to exclude from its operation children of ministers, consuls, and citizens or subjects of foreign states, born within the United States." ${ }^{187}$ The Court also addressed any "distinction between citizenship of the United States and citizenship of a state," stating that "it is only necessary that he should be born or naturalized in the United States to be a citizen of the Union" but state citizenship requires federal citizenship and residence. ${ }^{188} \mathrm{In}$ other words, while a person's state citizenship is dependent on residency, "every citizen of a state is ipso facto a citizen of the United States." 189

But what is a citizen of the United States? Is it a fictional corporate entity as believed by Sovereign Citizens? The answer is clear: a citizen for purposes of the Fourteenth Amendment's Citizenship Clause is the actual, physical person born or naturalized in the United States. ${ }^{190}$ First, it would be inapposite to include the phrase "born or naturalized" in the Citizenship Clause if the amendment was merely meant to establish the creation of artificial or corporate citizens. Corporations are formed, not born or naturalized. As illuminated by the Court, a corporation

is a citizen of the United States in the sense that a corporation organized under the laws of one of the states is a citizen of that state, but it is not within the clause of the Fourteenth Amendment which declares that native born and naturalized citizens of the United States shall be citizens of the state wherein they reside. ${ }^{191}$

And although corporations have some rights under the First, ${ }^{192}$ Fourth, ${ }^{193}$ and Fifth Amendments, ${ }^{194}$ they do not have the same rights as actual persons, such as the right against self-incrimination or right to bear arms. ${ }^{195}$

Second, the federal government likely cannot unilaterally revoke an individual's citizenship. In Afroyim v. Rusk, ${ }^{196}$ the Supreme Court held that "[o]nce acquired, this Fourteenth Amendment citizenship was not to be

187. Id. at 678 (quoting Slaughter-House Cases, 83 U.S. (16 Wall.) 36, 73 (1872)).

188. Id. at 677 ("Not only may a man be a citizen of the United States without being a citizen of a state, but an important element is necessary to convert the former into the latter. He must reside within the state to make him a citizen of it, but it is only necessary that he should be born or naturalized in the United States to be a citizen of the Union.")).

189. Wong Kim Ark, 169 U.S. at 716 (quoting Mr. Justice Story, in his Commentaries on the Constitution (section 1693)); Minor v. Happersett, 88 U.S. (21 Wall.) 162, 167 (1874) ("Whoever, then, was one of the people of either of these States when the Constitution of the United States was adopted, became ipso facto a citizen-a member of the nation created by its adoption. He was one of the persons associating together to form the nation, and was, consequently, one of its original citizens.").

190. Elk v. Wilkins, 112 U.S. 94, 101 (1884) ("[T]he Citizenship Clause contemplates two sources of citizenship, and two sources only: birth and naturalization.").

191. Bankers' Tr. Co. v. Texas \& P. Ry. Co., 241 U.S. 295, 309-10 (1916).

192. Citizens United v. Fed. Election Comm'n, 558 U.S. 310, 339 (2010).

193. Hale v. Henkel, 201 U.S. 43 (1906), overruled in part by Murphy v. Waterfront Comm'n of New York Harbor, 378 U.S. 52 (1964).

194. United States v. Martin Linen Supply Co., 430 U.S. 564 (1977).

195. Bellis v. United States, 417 U.S. 85, 88-89 (1974).

196. 387 U.S. 253 (1967). 
shifted, canceled, or diluted at the will of the Federal Government, the States, or any other governmental unit." 197 And although Sovereign Citizens believe that " $[\mathrm{t}]$ he only way the government will contract with you, is if you waive your inalienable rights and agree to be UNDER their jurisdiction," 198 citizenship is conferred upon birth or naturalization and cannot be lost "unless [the citizen] voluntarily relinquishes that citizenship."199 Moreover, if the "artificial" person's citizenship was merely a contractual agreement, UCC § 2-309(2) would permit that indefinite contract to "be terminated at any time by either party"- - something that the Government cannot do. 200

Third, if the citizenship conferred by the Fourteenth Amendment was contractual in nature, the Supreme Court's analysis and holdings in cases such as Wong Kim Ark would be wholly unnecessary. Instead of deciding whether a child born in the United States to foreign-born parents "becomes at the time of his birth a citizen of the United States, by virtue of the first clause of the fourteenth amendment of the constitution,"201 the Court would have asked whether the petitioner in that case was bound by contract or agreement. Because the Court instead analyzed the issue in terms of the historical context of birthright citizenship, the Sovereign Citizens' interpretation is implicitly flawed.

So what about the cases cited for the proposition that the federal government created a second class of citizenship for "artificial" persons? While it is true "that the distinction between citizenship of the United States and citizenship of a State is clearly recognized and established,"202 that distinction is not the one propagated by Sovereign Citizens. In Chisholm v. Georgia, ${ }^{203}$ the Supreme Court decided whether the Constitution abrogated a state's sovereign immunity in a suit brought by a citizen of another state. In finding that it did, the Court recounted the history of nations, sovereignty, and the natural order. ${ }^{204}$ The Court declared that the State "is an artificial person,"205 "subordinate to the People," and that:

197. Id. at 262 .

198. The TRUTH 1, supra note 30.

199. Afroyim, 387 U.S. at 268.

200. Afroyim, 387 U.S. at 268 ("The very nature of our free government makes it completely incongruous to have a rule of law under which a group of citizens temporarily in office can deprive another group of citizens of their citizenship. We hold that the Fourteenth Amendment was designed to, and does, protect every citizen of this Nation against a congressional forcible destruction of his citizenship, whatever his creed, color, or race.").

201. United States v. Wong Kim Ark, 169 U.S. 649, 649 (1898).

202. Slaughter-House Cases, 83 U.S. (16 Wall.) 36, 73 (1872)).

203. 2 U.S. (2 Dall.) 419 (1793), superseded by constitutional amendment, U.S. Const. amend XI, as stated in Pennhurst State School \& Hosp. Halderman, 465 U.S. 89 (1984).

204. Chisholm, 2 U.S. (2 Dall.) at 455-66.

205. Id. at 455 . 
The only reason, I believe, why a free man is bound by human laws, is, that he binds himself. Upon the same principles, upon which he becomes bound by the laws, he becomes amenable to the Courts of Justice, which are formed and authorised by those laws. If one free man, an original sovereign, may do all this; why may not an aggregate of free men, a collection of original sovereigns, do this likewise? ${ }^{206}$

As previously mentioned, Sovereign Citizens take this quote to mean that a state, as an artificial person created by the People, cannot rule over them as sovereigns. That view, however, is drawn from isolated words and phrases. In fact, Chisholm's holding rested on the notion that once sovereignty is relinquished by "We the People" to a government, or by the states to the federal government, a state cannot continue to claim sovereign immunity. ${ }^{207}$ And this is exactly what happened when the states ratified the Constitution and the Fourteenth Amendment. In fact, the Chisholm Court hypothetically questioned whether an entity can make a contract, break it, and then when called into court, avoid judgment "by declaring I am a Sovereign State." The Court's answer was clear: "Surely not."208 Accordingly, although a "State [is] considered as subordinate to the People[ ] . . everything else [is] subordinate to the State,"209 including individual citizens.

\section{Privileges or Immunities Clause}

The Fourteenth Amendment's Privileges or Immunities Clause "provides, among other things, that a State may not abridge "the privileges or immunities of citizens of the United States" or deprive "any person of life, liberty, or property, without due process of law." 210 In obiter dictum, the Supreme Court in the Slaughter-House Cases stated that these rights likely include the right to travel, "to demand the care and protection of the Federal government over his life, liberty, and property when on the high seas," "[t]he right to peaceably assemble and petition for redress of grievances, the privilege of the writ of habeas corpus," and "[t]he right to use the navigable waters of the United States." 211 These rights, however, are not based on the Declaration of Independence, as Sovereign Citizens claim. Instead, they owe "their existence to the Federal government, its National character, its Constitution, or its laws." 212

Looking to the possible list of privileges or immunities in the Slaughter-House Cases, the Sovereign Citizens' Natural Persons theory again falls

\footnotetext{
206. Id. at 456 .

207. Id. at 455 .

208. Id.

209. Id.

210. McDonald v. City of Chicago, Illinois, 561 U.S. 742, 754 (2010).

211. Slaughter-House Cases, 83 U.S. (16 Wall.) 36, 36 (1872)).

212. Id. at 79 .
} 
apart. These rights, such as the right to travel or to petition for a writ of habeas corpus, do not make sense if applied only to a "paper strawman." Artificial entities cannot travel across state lines or "use the navigable waters." They do not have a "life" to protect. Nor can they be produced in person, which is what habeas corpus literally means. ${ }^{213}$ And an actual person would have no standing to challenge evidence obtained in violation of their artificial person's rights. ${ }^{214}$ To read such an absurd result into the Fourteenth Amendment is contrary to common sense, the established canons of constitutional interpretation, and would improperly nullify Supreme Court precedent. ${ }^{215}$

\section{Other bases for jurisdiction}

"The Constitution grants Congress and the President the power to acquire, dispose of, and govern territory" within the United States. ${ }^{216}$ " "Territorial jurisdiction' exists as to 'territory over which a government or a subdivision thereof, or court, has jurisdiction." "217 Accordingly, "[e]very citizen or subject of another country, while domiciled here, is within the allegiance and the protection, and consequently subject to the jurisdiction, of the United States." 218 Therefore, it is by virtue of one's presence in the United States, absent some diplomatic exception, "that [gives] the Judiciary power to act." 219

The federal government, however, has limited power to prescribe what conduct constitutes a federal crime within its territorial bounds. So while "state criminal laws do not include the jurisdictional elements common in federal statutes," "in our federal system, 'Congress cannot punish felonies generally,' [and] it may enact only those criminal laws that are connected to

213. Johnson v. Eisentrager, 339 U.S. 763, 779 n.10 (1950) (quoting 2 THE OXFoRd ENGLISH DicTIONARY 2 (1933) ("Habeas Corpus ... thou (shalt) have the body (sc. in court). A writ issuing out of a court of justice ... requiring the body of a person to be brought before the judge or into the court for the purpose specified in the writ ... requiring the body of a person restrained of liberty to be brought before the judge or into court, that the lawfulness of the restraint may be investigated and determined." (internal quotation marks omitted))).

214. Rakas v. Illinois, 439 U.S. 128, 133 n.2 (1978) (“[A] person whose Fourth Amendment rights were violated by a search or seizure, but who is not a defendant in a criminal action in which the illegally seized evidence is sought to be introduced, would not have standing to invoke the exclusionary rule to prevent use of that evidence in that action.").

215. Sierra Club v. Watt, 608 F. Supp. 305, 327 (E.D. Cal. 1985) (“A reading of our Constitution that would, as a practical effect, stifle litigation as to national rules must be rejected on the basis that the law forbids the reading of statutes (much less the Constitution) to reach absurd results.").

216. Boumediene v. Bush, 553 U.S. 723, 765 (2008).

217. Gherebi v. Bush, 374 F.3d 727, 736 (9th Cir. 2004) (quoting Territorial Jurisdiction, BLACK's Law Dictionary (6th ed. 1990)).

218. United States v. Wong Kim Ark, 169 U.S. 649, 649 (1898).

219. Johnson v. Eisentrager, 339 U.S. 763, 771 (1950) (“[E]xtending constitutional protections beyond the citizenry" to an alien by virtue of his or her presence in the United States). 
one of its constitutionally enumerated powers, such as the authority to regulate interstate commerce. As a result, most federal offenses include, in addition to substantive elements, a jurisdictional one[.]" 220 Generally, this jurisdictional element is met through a "hook"; whereby through the Necessary and Proper Clause ${ }^{221}$ Congress can punish crimes that involve, among other provisions, its enumerated powers to regulate interstate and foreign commerce, to regulate bankruptcy and so forth. ${ }^{222}$ So although

[n] either Congress' power to criminalize conduct, nor its power to imprison individuals who engage in that conduct, nor its power to enact laws governing prisons and prisoners, is explicitly mentioned in the Constitution [, it] nonetheless possesses broad authority to do each of those things in the course of "carrying into Execution" the enumerated powers "vested by" the "Constitution in the Government of the United States[.]"223

As previously discussed, Congress created the lower federal courts under Article III, Section 1. ${ }^{224}$ As such, their jurisdiction is limited by both the Constitution ${ }^{225}$ and any bounds promulgated by Congress. ${ }^{226}$ Through its constitutional power, Congress has enacted 18 U.S.C. § 3231, which dictates that "[t]he district courts of the United States shall have original jurisdiction, exclusive of the courts of the States, of all offenses against the laws of the United States." 227 Similarly, Congress has granted jurisdiction to the federal courts of appeals "from all final decisions of the district courts of the United States," both civil and criminal. ${ }^{228}$ Despite Sovereign Citizens' contentions otherwise, federal courts have the statutory authority-granted by Congress through its constitutional authority - to hear cases over federal defendants.

220. Torres v. Lynch, 136 S. Ct. 1619, 1624 (2016) (quoting Cohens v. Virginia, 19 U.S. (6 Wheat.) 264, $428(1821))$.

221. U.S. Const. art. I, $\S 8$, cl. 18 ("The Congress shall have Power . . To make all Laws which shall be necessary and proper for carrying into Execution the foregoing Powers, and all other Powers vested by this Constitution in the Government of the United States, or in any Department or Officer thereof.").

222. United States v. Comstock, 560 U.S. 126, 136 (2010) ("[T]o regulate interstate and foreign commerce, to enforce civil rights, to spend funds for the general welfare, to establish federal courts, to establish post offices, to regulate bankruptcy, to regulate naturalization, and so forth.”).

223. Comstock, 560 U.S. at 137.

224. U.S. Const. art. III, $\S 1$.

225. Id. § 2 .

226. U.S. Const. art. I, § 8, cl. 9; The Francis Wright, 105 U.S. 381, 385-86 (1881) ("While the appellate power of this Court extends to all cases within the judicial power of the United States, actual jurisdiction is confined within such limits as Congress sees fit to describe ... What these powers shall be, and to what extent they shall be exercised, are, and always have been, proper subjects of legislative control.").

227. 18 U.S.C. $\S 3231$ (2018).

228. 28 U.S.C. $\S 1291$ (2018). 


\section{Conclusion}

The Fourteenth Amendment's Citizenship Clause and Privileges or Immunities Clause did not establish a second class of citizenship for "artificial persons" by virtue of a contract with the federal government. All persons born or naturalized within the United States, and those non-citizens domiciled in the United States, are subject to its jurisdiction. Moreover, Congress has the constitutional power to criminalize behavior that falls within its enumerated legislative powers and has statutorily granted the federal courts authority to hear and decide federal criminal and civil cases.

\section{The financial authority of the U.S. Government and hidden funds}

\section{Income tax}

A tangential, but related, first issue in the Redemption Scheme is the federal government's power to tax citizens' income. Sovereign Citizens often challenge the government's authority or the Internal Revenue Service's validity on the ground that a federal income tax is an unconstitutional direct tax that should be apportioned. This argument, however, has been roundly rejected by federal courts. Under the Sixteenth Amendment, "Congress shall have power to lay and collect taxes on incomes, from whatever source derived, without apportionment among the several States, and without regard to any census or enumeration." 229 Congress gave the district courts jurisdiction "to render such judgments and decrees as may be necessary or appropriate for the enforcement of the internal revenue laws." 230

Additionally, Congress has given the federal government the right to obtain a lien against "all property and rights to property, whether real or personal" of any person who neglects or refuses to pay their taxes. ${ }^{231}$ The United States may enforce this lien by commencing an action in federal court, joining all parties with an interest in the property, and obtaining a judicial sale of the real property. ${ }^{232}$ Furthermore, "the Internal Revenue Service is organized to carry out the broad responsibilities of the Secretary of the Treasury under $\S 7801$ (a) of the 1954 Code for the administration and enforcement of the internal revenue laws." ${ }^{233}$ As the Supreme Court has

229. U.S. Const. amend. XVI.

230. 26 U.S.C. $§ 7402(a)$ (2018); see also 28 U.S.C. $\$ \$ 1340,1345,1357$ (2018).

231. Id. $\$ 6321$ (2018).

232. 26 U.S.C. $\$ 7403$ (2018); United States v. Rodgers, 461 U.S. 677, 691-92 (1983).

233. Donaldson v. United States, 400 U.S. 517, 534 (1971). The Secretary of the Treasury has full authority to administer and enforce the internal revenue laws and has the power to create an agency to enforce those laws. 26 U.S.C. $\$ 7801$. Its head, the Commissioner of Internal Revenue, is responsible to administer and supervise the execution and application of the internal revenue laws. 26 U.S.C. $§$ 7803(a) (2018). 
directly rejected similar challenges to the federal government's power, ${ }^{234}$ courts routinely strike down any challenges to the federal government's power to tax citizens' income as frivolous. ${ }^{235}$

\section{Redeeming the Redemption Scheme}

That the Redemption Scheme does not work is beyond dispute. The Office of the Comptroller of the Currency and the U.S. Department of Treasury have explicitly warned individuals not to participate or believe in the Redemption Scheme. First, the various permutations of the scheme "have no substance in law or finance." 236 Second, "[t]he creation and presentment of these documents may be a violation" of federal law, 18 U.S.C. $§ 514$, "and the person(s) using such fictitious instruments may be subject to criminal prosecution." 237 Third, "[r]egardless of how such instruments or documents are titled or whether they appear authentic, they are worthless, have no legal validity, and are not payable through the United States Treasury, the Secretary of the Treasury, the Comptroller of the Currency, or any other federal or state agency." 238

In effect, because social security numbers and birth certificates do not evidence hidden accounts, any "bill of exchange drawn on the account and the subsequent chargeback have no legal effect and are not sufficient either to create a right to payment or to create an equitable remedy for breach of performance that gives rise to a right to payment." 239 As for the purported proof that redemption is possible, neither the Joint Resolution nor Guaranty Trust permit the redemption of funds in some hidden account. ${ }^{240}$ House

234. Brushaber v. Union Pac. R.R. Co., 240 U.S. 1 (1916); Stanton v. Baltic Mining Co., 240 U.S. 103 (1916)

235. See, e.g., United States v. Hilgeford, 7 F.3d 1340, 1342 (7th Cir. 1993) (rejecting as frivolous and "shop worn" the argument that an individual is a sovereign citizen of a state who is not subject to federal taxing authority); Lonsdale v. United States, 919 F.2d 1440, 1448 (10th Cir. 1990) (rejecting as frivolous arguments concerning the government's authority to impose income tax and listing repeatedly rejected arguments).

236. Office of the Comptroller of the Currency, Fraudulent Debt Elimination Schemes, United States Department of Treasury, https://perma.cc/YM6K-YSX9 (describing "[t]he use of a nonexistent 'trust account' supposedly held in a person's name at the United States Department of the Treasury or some other part of the federal government" as one of the "fraudulent processes used to ... 'eliminate' debt").

237. Office of the Comptroller of the Currency, Fictitious Financial Instruments: Worthless Sight Drafts, Bills of Exchange, Due Bills and Redemption Certificates, United States Department of Treasury, https://perma.cc/3FEB-7U3A; Bogus Sight Drafts/Bills of Exchange Drawn on the Treasury, Treasury Direct, https://perma.cc/SJJ4-H2CY ("Drawing [Bills of Exchange] on the U.S. Treasury is fraudulent and a violation of federal law. The theory behind their use is bogus and incomprehensible.").

238. Office of the Comptroller of the Currency, Illegal Financial Activity: Fictitious Debt Elimination Schemes, United States Department of Treasury, https://perma.cc/L2TS-N7UC.

239. In re Fachini, 470 B.R. 638, 642 (Bankr. M.D. Ga. 2012).

240. Bryant v. Wash. Mut. Bank, 524 F. Supp. 2d 753, 760 (W.D. Va. 2007), aff'd, 282 F. App’x 260 (4th Cir. 2008) ("Most importantly, the alleged legal bases for [a redemption scheme] claim, House 
Joint Resolution 192 dealt with redemption of Liberty Bonds following World War I, ${ }^{241}$ and in Guaranty Trust, the Supreme Court held that the Joint Resolution forbade the enforcement of a provision in certain contracts that payment of a debt was to be made in Dutch guilders. ${ }^{242}$

\section{The Federal Reserve and Federal Reserve Notes}

The remaining tenets of the Redemption Scheme can be broken into two pieces: (1) the private nature of the Federal Reserve (or alternatively the Internal Revenue Service), and (2) the validity of Federal Reserve Notes as legal tender.

First, although Sovereign Citizens believe that the Federal Reserve Act of December 23, $1913^{243}$ created the Federal Reserve as a "private corporation," the Federal Reserve Banks are in fact "government instrumentalities"244 that "play as the government's fiscal agents." 245 And although they are not government agencies or departments for most purposes, ${ }^{246}$ the Federal Reserve's power stems from Congress, and the activities of member banks are governmental. ${ }^{247}$ So "[w]hile savings and loan associations may in many ways be analogized to private corporations, federal reserve banks, by contrast, are plainly and predominantly fiscal arms of the federal government." 248 The Internal Revenue Service, on the other hand, "is organized to carry out the broad responsibilities of the Secretary of the Treasury under $\$ 7801$ (a) of the 1954 Code for the administration and enforcement of the internal revenue laws." 249 Congress has granted the Secretary of the Treasury authority to administer and enforce the internal revenue laws and has

Joint Resolution 192 and Guaranty Tr. Co. of New York v. Henwood, 307 U.S. 247 (1939), address nothing more than the U.S. monetary shift away from the gold standard and provide absolutely no support for [a plaintiff's redemption scheme] position.").

241. See Perry v. United States, 294 U.S. 330, 346-47 (1935).

242. Guaranty Tr. Co., 307 U.S. at 258-59.

243. 12 U.S.C. $\S \S 221-522$ (2018).

244. Fed. Land Bank of St. Louis v. Priddy, 295 U.S. 229, 237 (1935); Fed. Res. Bank of St. Louis v. Metrocentre Imp. Dist. No. 1, 657 F.2d 183, 186 (8th Cir. 1981), aff'd, 455 U.S. 995 (1982).

245. Scott v. Fed. Res. Bank of Kansas City, 406 F.3d 532, 535 (8th Cir. 2005).

246. United States Shipping Bd. Emergency Fleet Corp. v. W. Union Tel. Co., 275 U.S. 415, 425-26 (1928) ("Instrumentalities like the national banks or the federal reserve banks, in which there are private interests, are not departments of the government.").

247. Fed. Land Bank of St. Paul v. Bismarck Lumber Co., 314 U.S. 95 (1941) ("It also follows that when Congress constitutionally creates a corporation through which the federal government lawfully acts, the activities of such corporation are governmental."); Berini v. Fed. Reserve Bank of St. Louis, Eighth Dist., 420 F. Supp. 2d 1021, 1029 (E.D. Mo. 2005).

248. Fed. Reserve Bank of Boston v. Comm'r of Corps. \& Taxation of Com. of Mass., 499 F.2d 60 , 62 (1st Cir. 1974).

249. Donaldson v. United States, 400 U.S. 517 (1971). 
the power to create an agency, such as the Internal Revenue Service, to enforce those laws. ${ }^{250}$

Next, Sovereign Citizens claim that Article 1, § 10, clause 1, which states that "No State shall . . make anything but gold and silver Coin a Tender in Payment of Debts . . .," invalidates the Federal Reserve Note. ${ }^{251}$ First, Article I, Section 8, clause 5, of the Constitution provides that Congress has the enumerated power " $[t] 0$ coin money, regulate the value thereof, and of foreign coin, and fix the standard of weights and measures." 252 "The power to coin money necessarily carries with it the power to declare what is money, and the constitution does not limit Congress to gold and silver coin. Section 8 sets forth the powers of Congress, while $\$ 10$ imposes a restriction on the states." 253 Second, under 31 U.S.C. $§ 5103$, Congress has mandated that "United States coins and currency (including Federal reserve notes and circulating notes of Federal reserve banks and national banks) are legal tender for all debts, public charges, taxes, and dues. Foreign gold or silver coins are not legal tender for debts." 254 Moreover, the U.S. Dollar is not backed by "the U.S. citizens themselves . . a as collateral to pay off [bankruptcy] debt," ${ }^{255}$ but rather the collateral assets that Federal Reserve Banks post in order to obtain the notes. ${ }^{256}$ These constitutional257 statutes foreclose any Sovereign Citizen argument to the contrary. ${ }^{258}$

\section{Conclusion}

The Federal Reserve has the statutory authority to print Federal Reserve Notes, and acts as a government instrumentality in doing so. No secret trust accounts exist, and the Redemption theory is based on faulty or limited readings of Supreme Court cases, inapplicable UCC citations, and overreliance on innocuous capitalization and documents that merely track citizens' birth and employment.

250. 26 U.S.C. $\S 7801$ (2018).

251. U.S. Const. art. I, § 10, cl. 1; The TRUTH 3, supra note 85.

$\mathbf{R}$

252. U.S. Const. art. I, $\S 8$, cl. 5 .

253. In re Yuska, 571 B.R. 424, 428 (Bankr. N.D. Iowa 2017).

254. 31 U.S.C. $\$ 5103$.

255. The TRUTH 3, supra note 85.

256. 12 U.S.C. $\S 412$ (2018).

257. Julliard v. Greenman, 110 U.S. 421 (1884); United States v. Wangrud, 533 F.2d 495, 495 (9th Cir. 1976).

258. Rahman El v. First Franklin Fin. Corp., No. 09-CV-10622, 2009 WL 3876506, at *7 (E.D. Mich. Nov. 17, 2009) (collecting cases rejecting the argument "that paper money does not have value because it is not backed by either gold or silver"). 


\section{Every citizen's right to travel (between states and subject to regulation)}

In relying on specific language quoted from state court opinions and dictionaries, Sovereign Citizens mistakenly believe that their interpretations of isolated words in dictionaries and cases are binding; however, federal and state law belie such a narrow interpretation of traveling. Moreover, the four cases Sovereign Citizens most often cite do not stand for the proposition that individuals have an unfettered right to travel. In fact, those cases explicitly assert that the state does have the power to regulate automobiles of all types and to require a license and registration as a prerequisite to traveling. ${ }^{259}$ Lastly, the Supreme Court has unmistakably upheld the constitutionality of police stops and DUI or immigration checkpoints without probable cause.

\section{Specific words}

Because a right to travel does not and cannot be based on specific words derived from dictionary definitions, Sovereign Citizens are left only with 18 U.S.C. $\S 31$ 's definition of "motor vehicle" to support the claim that only a vehicle used for commerce requires a license. That statute, however, defines terms used under Title 18 of the United States Code-the main criminal code of the federal government of the United States. And because Congress may only "regulate and protect the instrumentalities of interstate commerce, or persons or things in interstate commerce," 260 Congress necessarily had to define "motor vehicles" used in federal crimes as things "used for commercial purposes" to satisfy the jurisdictional "hook." Under the Constitution, it is the states-not the federal government- that have the power to regulate vehicles not used in interstate commerce.

\section{The actual right to travel}

While the four cases often quoted by Sovereign Citizens appear, at first glance at least, to support an individual's right to unfettered travel, the oft-quoted language does not appear verbatim in the record. The most complete quotations even undercut their claims. In Chicago Motor Coach Co. v. City of Chicago, the Illinois State Supreme Court stated that "[e]ven the Legislature has no power to deny to a citizen the right to travel upon the

259. Kent v. Dulles, 357 U.S. 116, 132 (1958); Schactman v. Dulles, 225 F.2d 938, 940-41 (D.C. Cir. 1955); Thompson v. Smith, 154 S.E. 579, 583 (Va. 1930); Chicago Motor Coach Co. v. City of Chicago, 169 N.E. 22, 25 (Ill. 1929).

260. United States v. Lopez, 514 U.S. 549, 558 (1995) (citing Shreveport Rate Cases, 234 U.S. 342 (1914)); see also U.S. Const. art. I, § 8. 
highway and transport his property in the ordinary course of his business or pleasure, though this right may be regulated in accordance with the public interest and convenience." ${ }^{261}$ Likewise, Thompson v. Smith, from the Supreme Court of Appeals of Virginia, stated that "[t]he right of a citizen to travel upon the public highways and to transport his property thereon in the ordinary course of life and business is a common right which he has under his right to enjoy life and liberty, to acquire and possess property, and to pursue happiness and safety." ${ }^{262}$ In Kent v. Dulles, ${ }^{263}$ the United States Supreme Court held that " $[t]$ he right to travel is a part of the 'liberty' of which the citizen cannot be deprived without the due process of law under the Fifth Amendment."264 The Court of Appeals for the District of Columbia affirmed this holding in Shachtman v. Dulles, stating that "[t]he right to travel, to go from place to place as the means of transportation permit, is a natural right subject to the rights of others and to reasonable regulation under law."265

Looking to the context of these cases, however, dispels any assertion that they establish or confirm an unfettered right to travel without a license or registration. In Chicago, the court specifically noted that "it has been uniformly held that the state, in the exercise of the police power, may regulate their speed and provide other reasonable rules and restrictions as to their use." 266 Similarly, the court in Thompson noted that "[t]he right of a citizen to travel and transport property and to use the ordinary and usual conveyances of the day may, under the police power, be regulated by the city in the interest of public safety and welfare." 267 So while these state court opinions are not binding interpretations of the U.S. Constitution, they also do not support the Sovereign Citizens' selective use of case law to support an unfettered right to travel.

We next turn to federal case law. Looking to the context in Shachtman, we find that " $[\mathrm{t}]$ he right to travel, to go from place to place as the means of transportation permit, is a natural right subject to the rights of others and to reasonable regulation under law." 268 But even this case, being from the D.C. Circuit, is not the final authority. For that, we look to Kent and other Supreme Court cases on the right to travel. In Kent, the Court did state that " $[t]$ he right to travel is a part of the 'liberty' of which the citizen cannot be

261. Chicago Motor Coach, 169 N.E. at 25, abrogated by American Tel. \& Tel. Co. v. Village of Arlington Heights, No. 72315, 1992 WL 356097 (Ill. Dec. 4, 1992).

262. Thompson, 154 S.E. at 583.

263. 357 U.S. 116 (1958).

264. Kent, 357 U.S. at 125.

265. Shachtman, 225 F.2d at 941.

266. Chicago Motor Coach Co., 169 N.E. at 25.

267. Thompson, 154 S.E. at 579.

268. Shachtman, 225 F.2d at 941 (emphasis added). 
deprived without the due process of law under the Fifth Amendment."269 This statement was made, however, in the context of whether the Secretary of State had the statutory authority to promulgate regulations denying passports (he did not). ${ }^{270}$ And in that case, the Court's sole issue was whether Congress had authorized the curtailment of the right to travel through the issuing of passports. ${ }^{271}$

In Hendrick v. State of Maryland, ${ }^{272}$ the Supreme Court addressed the very right to travel (absent state regulation) that Sovereign Citizens seek to invoke. ${ }^{273}$ "[A] state may rightfully prescribe uniform regulations necessary for public safety and order in respect to the operation upon its highways of all motor vehicles, those moving in interstate commerce as well as others." 274 Such regulations are "but an exercise of the police power uniformly recognized as belonging to the states and essential to the preservation of the health, safety, and comfort of their citizens." 275 In later cases, the Court has repeatedly affirmed the states' power in this realm. ${ }^{276}$ Unfortunately for Sovereign Citizens, this binding interpretation confirms that a state may require a license, registration, or other documentation, regardless of whether the vehicle is used for commerce or private purposes.

Where then, does the Constitution's guaranteed right to travel protect a citizen? In Saenz v. Roe, ${ }^{277}$ the Court expounded upon citizens' fundamental and constitutional right to travel:

The 'right to travel' discussed in our cases embraces at least three different components. It protects the right of a citizen of one State to enter and to leave another State, the right to be treated as a welcome visitor rather than an unfriendly alien when temporarily present in the second State, and, for

269. Kent, 357 U.S. at 125.

270. Id. at 127 .

271. Id. ("Freedom to travel is, indeed, an important aspect of the citizen's 'liberty.' We need not decide the extent to which it can be curtailed. We are first concerned with the extent, if any, to which Congress has authorized its curtailment.").

272. 235 U.S. 610 (1915).

273. Id. at 622 .

274. Id.

275. Id.

276. Reitz v. Mealey, 314 U.S. 33, 36 (1941) ("The use of the public highways by motor vehicles, with its consequent dangers, renders the reasonableness and necessity of regulation apparent. The universal practice is to register ownership of automobiles and to license their drivers. Any appropriate means adopted by the states to insure competence and care on the part of its licensees and to protect others using the highway is consonant with due process."); Hess v. Pawloski, 274 U.S. 352, 356 (1927) ("Motor vehicles are dangerous machines, and, even when skillfully and carefully operated, their use is attended by serious dangers to persons and property. In the public interest the state may make and enforce regulations reasonable calculated to promote care on the part of all, residents and nonresidents alike, who use its highways.").

277. 526 U.S. 489 (1999). 
those travelers who elect to become permanent residents, the right to be treated like other citizens of that State. ${ }^{278}$

The first right (of ingress and egress), which is not found in the Constitution but "was expressly mentioned in the text of the Articles of Confederation, may simply have been 'conceived from the beginning to be a necessary concomitant of the stronger Union the Constitution created." "279 "The second component of the right to travel is, however, expressly protected by the text of the Constitution." ${ }^{280}$ Pointing to Article IV, § 2,281 the Court held that "by virtue of a person's state citizenship, a citizen of one State who travels in other States, intending to return home at the end of his journey, is entitled to enjoy the "Privileges and Immunities of Citizens in the several States' that he visits." 282 The third right "of the newly arrived citizen to the same privileges and immunities enjoyed by other citizens of the same State," is protected by an individual's state citizenship as well as U.S. citizenship under the Fourteenth Amendment. ${ }^{283}$ These rights therefore protect individuals from certain state actions, such as being taxed at state borders, ${ }^{284}$ or being subject to durational residence requirements for eligibility for nonemergency free medical care ${ }^{285}$ and certain forms of public assistance. ${ }^{286}$ The right to travel does not, however, protect citizens from being stopped by state police for speeding or driving without the required documentation.

\section{Border and DUI checkpoints}

Having established the Supreme Court's view of constitutionally valid exercises of state power over traveling, I next examine whether police must articulate their reasonable suspicion of a crime being violated and whether DUI and border checkpoints are an unlawful form of taxation. ${ }^{287}$

\section{a. Reasonable articulable suspicion}

"An individual operating or traveling in an automobile does not lose all reasonable expectation of privacy simply because the automobile and its

278. Id. at 500 .

279. Id. at 501 (quoting United States v. Guest, 383 U.S. 745, 748 (1966)).

280. Id.

281. "The Citizens of each State shall be entitled to all Privileges and Immunities of Citizens in the several States."

282. Saenz, 526 U.S. at 501.

283. Id. at 502 (quoting U.S. Const. amend. XIV).

284. Crandall v. State of Nevada, 73 U.S. 35 (1867).

285. Mem'l Hosp. v. Maricopa County, 415 U.S. 250, 269 (1974).

286. Shapiro v. Thompson, 394 U.S. 618, 642 (1969), overruled in part by Edelman v. Jordan, 415 U.S. 651 (1974).

287. Sovereign Right to Operate, supra note 124. 
use are subject to government regulation." 288 Thus under the Fourth Amendment, "[t]emporary detention of individuals during the stop of an automobile by the police, even if only for a brief period and for a limited purpose, constitutes a 'seizure' of 'persons[.]'" 289 In Delaware v. Prouse, the Supreme Court addressed whether police may pull over vehicles at random to check for a driver's license or registration absent probable cause. Holding that police may not, the Court stated:

[E]xcept in those situations in which there is at least articulable and reasonable suspicion that a motorist is unlicensed or that an automobile is not registered, or that either the vehicle or an occupant is otherwise subject to seizure for violation of law, stopping an automobile and detaining the driver in order to check his driver's license and the registration of the automobile are unreasonable under the Fourth Amendment. ${ }^{290}$

The Court also limited this holding, however, by affirming the states' right to "spot check" or question "all oncoming traffic at roadblock-type stops[.]" 291 In other words, although police may not randomly pull over vehicles absent an articulable and reasonable suspicion of some wrongdoing, it may randomly inspect vehicles at a check point.

But do police have to articulate their reasonable suspicion to the driver? In United States v. Sokolow, ${ }^{292}$ the Supreme Court held that an officer "must be able to articulate something more than an inchoate and unparticularized suspicion or hunch. The Fourth Amendment requires some minimal level of objective justification for making the stop." 293 Moreover, an investigative detention based on reasonable articulable detention must be temporary and last no longer than is necessary to effectuate the purpose of the stop. ${ }^{294}$ But the required articulation is reviewed only after the stop to determine whether the stop was justified. The Court further elaborated on this holding in Whren v. United States, holding that the reasonable, articulable suspicion is viewed objectively, and does not depend "on the actual motivations of the individual officers involved." 295 Therefore, the articulation (or lack thereof) at the time of the stop does not matter, because courts will review the police action under the totality of the circumstances. In fact, police officers can lie about the reason they stop a driver. ${ }^{296}$

288. Delaware v. Prouse, 440 U.S. 648, 662 (1979).

289. Whren v. United States, 517 U.S. 806, 809-10 (1996).

290. Prouse, 440 U.S. at 663 (emphasis added).

291. Id.

292. 490 U.S. 1 (1989).

293. Sokolow, 490 U.S. at 7.

294. Florida v. Royer, 460 U.S. 491, 500 (1983).

295. Whren, 517 U.S. at 813.

296. United States v. Magallon-Lopez, 817 F.3d 671, 675 (9th Cir. 2016). 
In Devenpeck v. Alford ${ }^{297}$ the Court rejected a citizen's constitutional right to have an officer articulate the reason for arrest during the arrest. ${ }^{298}$ "While it is assuredly good police practice to inform a person of the reason for his arrest at the time he is taken into custody, we have never held that to be constitutionally required." 299 The time to challenge the police officer's actions come later, in court. ${ }^{300}$ In light of the Court's holding in Whrenthat the constitutional reasonableness of traffic stop does not depend on actual motivations of the individual officers involved-Devenpeck's rationale likely extends to traffic stops. ${ }^{301}$ For if no reason is required during arrest, it seems fair to assume that no reason would be required during a temporary detention, as the invasion of a person's liberty is less intrusive during a traffic stop than it is during an arrest. Accordingly, there does not appear to be support under the U.S. Constitution for the proposition that police officers need inform a driver of their reasonable and articulable basis for a traffic stop.

\section{b. DUI and border checkpoints}

As to the constitutional validity of DUI and border checkpoints, the Supreme Court has been clear. In Michigan Department of State Police v. Sitz, ${ }^{302}$ the Court addressed "the initial stop of each motorist passing through a checkpoint and the associated preliminary questioning and observation by checkpoint officers." 303 By balancing "the State's interest in preventing drunken driving, the extent to which this system can reasonably be said to advance that interest, and the degree of intrusion upon individual motorists who are briefly stopped," the Court held that DUI or sobriety checkpoints are consistent with the Fourth Amendment. ${ }^{304}$ Following a similar balancing test in United States v. Martinez-Fuerte, the Court held "that stops for brief questioning routinely conducted at permanent [border patrol] checkpoints are consistent with the Fourth Amendment and need not be authorized by warrant." 305 In sum, the U.S. Constitution does not protect drivers from being stopped at DUI or border checkpoints for limited, investigatory stops.

297. 543 U.S. 146 (2004).

298. Id. at 155 .

299. Id.

300. Id. at 155 n.3.

301. Whren, 517 U.S. at 813.

302. 496 U.S. 444 (1990).

303. Sitz, 496 U.S. at 450-51.

304. Id. at 455 .

305. United States v. Martinez-Fuerte, 428 U.S. 543, 566 (1976). 


\begin{tabular}{lllll}
\hline |ljciprod01/productnlMIMON180-2IMON202.txt & unknown & Seq: 41 & 1-AUG-19 & 11:52 \\
\hline
\end{tabular}

\section{Conclusion}

Voicing concerns over the federal government's overreach into citizens' lives, Sovereign Citizens make the unfortunate mistake of relying on non-binding or irrelevant legal definitions and misreading judicial opinions to avoid regulation or invoke rights that have no basis in law. The Supreme Court, as final arbiter of federal constitutional law and rights, has repeatedly upheld the federal courts' jurisdiction over adjudication of federal crimes by citizens. Citizens of the United States, born or naturalized, cannot challenge the courts' jurisdiction by invoking their own sovereignty or fringe on a flag. To the contrary, all citizens are subject to the courts' jurisdiction and their conduct-be it driving or paying taxes-can be regulated by the state and federal government without a citizen's consent. Accordingly, courts have routinely denied every Sovereign Citizen claim involving a lack of jurisdiction, ${ }^{306}$ the Redemption Scheme, ${ }^{307}$ the right to travel, ${ }^{308}$ and fringe on flags, ${ }^{309}$ as proof that their claims are unavailing as law. But despite having no basis in the law, the courts and civil servants should nevertheless rebut Sovereign Citizen claims with the actual law of the United States. These Americans-albeit misguided and ill-informed-honestly believe that they have found the key to challenging government overreach. In reality, they have only purchased snake oil that is bound to ensure more government reach into their lives. As such, it is the legal community's duty to inform them of their actual rights under the Constitution and thereby avert more violent or pseudolegal responses.

306. See Appendix I.

307. See Appendix II.

308. See Appendix III.

309. See Appendix IV. 
APPENDIX I

\section{Lack of Jurisdiction}

\section{First Circuit}

United States v. Nobrega, No. 1:10-cr-00186-JAW, 2014 WL 3405461 (D. Me. July 11, 2014); Augustinowicz v. Nevelson, No. 10-cv-564-PB, 2011 WL 6300962 (D.N.H. Dec. 16, 2011); Rowe v. I.R.S., No. 06-27-P-S, 2006 WL 1300599 (D. Me. May 9, 2006).

\section{Second Circuit}

Santana v. United States, No. 16-cv-5750, 2017 WL 2470834 (S.D.N.Y. June 6, 2017); Buchholz-Kaestner v. Fitzgerald, No. 6:16-CV-0604, 2017 WL 2345589 (GTS/TWD) (N.D.N.Y. May 30, 2017); United States v. Barnwell, No. 15 Cr. 620 (NSR), 2017 WL 1063457 (S.D.N.Y. Mar. 20, 2017); Shabazz v. Dzurenda, No. 3:16cv62(MPS), 2016 WL 4203395 (D. Conn. Aug. 9, 2016); Faltine v. Murphy, No. 15-CV-3961 (RRM) (LB), 2016 WL 3162058 (E.D.N.Y. June 3, 2016); Buczek v. Cotter, No. 14-CV1024S, 2015 WL 9413885 (W.D.N.Y. Dec. 22, 2015); Townsend v. New York, No. 14-CV-6079 (CBA)(LB), 2015 WL 4692604 (E.D.N.Y. Aug. 6, 2015); Mishtaku v. City of New York, No. 14-CV-839 (VSB), 2015 WL 13002182 (S.D.N.Y. May 4, 2015); Wik v. Kunego, No. 11-CV-6205-CJS, 2014 WL 1746477 (W.D.N.Y. Apr. 30, 2014); Paul v. New York, No. 13-CV-5047 (SJF)(AKT), 2013 WL 5973138 (E.D.N.Y. Nov. 5, 2013); United States v. Baker, No. 1:06-cr-19-jgm-1, 2013 WL 4804299 (D. Vt. Sept. 9, 2013); Harris v. United States, No. 00 CR. 105(RPP), 04 Civ. 1113(RPP), 2005 WL 1925435 (S.D.N.Y. Aug. 10, 2005).

\section{Third Circuit}

United States v. James, 712 F. App'x 154 (3d Cir. 2017); Smiles v. Cnty. of Berks, No. 17-3543, 2017 WL 3496486 (E.D. Pa. Aug. 14, 2017); United States v. Young, No. 1:16-CR-161, 2017 WL 3087744 (M.D. Pa. July 20, 2017); Shover v. Brubaker, No. 3:17-CV-0518, 2017 WL 2080244 (M.D. Pa. May 15, 2017); United States v. Hameed, No. 15-563-01, 2017 WL 660845 (E.D. Pa. Feb. 17, 2017); Lewis-Bey v. Wolff, No. 16-3685, 2016 WL 3997248 (E.D. Pa. July 25, 2016); Danihel v. Office of the President, No. 14-6880, 2015 WL 1954269 (E.D. Pa. Apr. 29, 2015); FirstBank P.R. v. Christopher, No. 2013-0093, 2015 WL 883830 (D.V.I. Feb. 27, 2015); Cofield v. United States, No. 14-2637 (RMB), 2014 WL 1745018 (D.N.J. Apr. 30, 2014); McManus v. Kameen, No. 3:CV-14-469, 2014 WL 


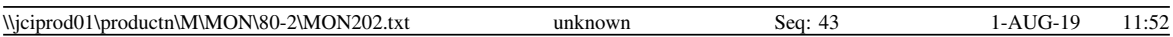

1745884 (M.D. Pa. Apr. 30, 2014); Elliot v. Giorla, No. 12-5799, 2013 WL 5410992 (E.D. Pa. Sept. 27, 2013); Avila v. New Jersey, No. 13-0779 (JAP), 2013 WL 4597096 (D.N.J. Aug. 29, 2013); Minister Truth Ali ex rel. Williams v. New Jersey, No. 12-2797 (RBK), 2012 WL 4959488 (D.N.J. Oct. 17, 2012); United States v. Young, No. 06-710, 2012 WL 3517332 (E.D. Pa. Aug. 15, 2012); United States v. Young, Nos. 08-1532, 07-3533, 2012 WL 1694344 (E.D. Pa. May 12, 2012); Banks v. United States, No. 04-176, 2012 WL 253183 (W.D. Pa. Jan. 26, 2012); Arndt v. Pennsylvania, No. 3:11-CV-856, 2011 WL 3876161 (M.D. Pa. Aug. 31, 2011); Avila v. Warden of New Jersey State Prison, No. 10-5318 (NLH), 2011 WL 2148345 (D.N.J. May 31, 2011); Simmons v. Colleran, No. Civ.A. 051127, 2005 WL 2783001 (E.D. Pa. Oct. 24, 2005).

\section{Fourth Circuit}

Butler v. South Carolina, No. 8:17-2927-BHH-JDA, 2017 WL 6276179 (D.S.C. Nov. 14, 2017); Loney v. North Carolina, No. 7:17-CV-38-FL, 2017 WL 4838844 (Oct. 26, 2017); Bey v. Ziegler, No. 2:17-cv-2434RMG-MGB, 2017 WL 4797798 (D.S.C. Sept. 25, 2017); Wells Fargo Bank, N.A. v. C.J.B. Holding \& Tr. Co., No. 2:17-1446-RMG-BM, 2017 WL 4570401 (D.S.C. Sept. 19, 2017); United States v. Nabaya, No. 3:17cr3, 2017 WL 3880660 (E.D. Va. Sept. 5, 2017); Christiana Tr. v. Davis, No. 2:17-1502-RMG-BM, 2017 WL 3911029 (D.S.C. Aug. 22, 2017); Bank of America, N.A. v. Baxter, No. 3:17-1447-MBS, 2017 WL 3473991 (D.S.C. Aug. 14, 2017); United States v. Chatman, No. 4:17-cv-01556RBH-KDW, 2017 WL 3704832 (D.S.C. July 28, 2017); South Carolina v. Montgomery, No. 4:17-cv-01555-RBH-KDW, 2017 WL 3530523 (D.S.C. July 27, 2017); Bey v. Jefferson, No. 2:17-1007-RMG, 2017 WL 1956979 (D.S.C. May 11, 2017); Rodger II of Family of Atwood v. Connor, No. 2:17-cv-01180, 2017 WL 2269005 (S.D.W. Va. May 4, 2017); Patrick of Family of Morgan v. Hughes, No. 1:17-cv-01208, 2017 WL 6993029 (S.D. Va. May 4, 2017); United States v. Shapat Ahdawan Nabaya, No. 3:17cr3, 2017 WL 1424802 (E.D. Va. Apr. 19, 2017); Pleasant-Bey v. City of Baltimore, No. DKC-16-3879, 2016 WL 7491624 (D. Md. Dec. 30, 2016); Ferguson-El v. Horton, No. 7:16-cv-00120, 2016 WL 7031804 (W.D. Va. Dec. 1, 2016); Lee-Bey v. Perry, No. 3:16cv195-FDW, 2016 WL 7007541 (W.D.N.C. Nov. 29, 2016); Rejuney v. Chesapeake Circuit Court, No. 3:16CV194-HEH, 2016 WL 5402217 (E.D. Va. Sept. 26, 2016); Bank of America v. Baxter, No. 3:16-1231-MBS, 2016 WL 4143325 (D.S.C. Aug. 3, 2016); Akbar v. Clarke, No. 1:15cv338 (AJT/TCB), 2016 WL 4150456 (E.D. Va. Aug. 1, 2016); Bey v. Cooper, No. 3:15-cv-00539-FDW-DSC, 2016 WL 3095228 (W.D.N.C. June 1, 2016); James-Bey v. Stancil, No. 3:13cv386-FDW, 2016 WL 2654585 (W.D.N.C. May 10, 2016); Sharma v. 
Unknown Respondent, No. 5:15-HC-2209-BO, 2016 WL 8667801 (E.D.N.C. Mar. 30, 2016); Heaggins v. Joyner, No. 1:15cv281-FDW, 2016 WL 110599 (W.D.N.C. Jan. 8, 2016); Gaskins v. South Carolina, No. 2:15cv-2589 DCN, 2015 WL 6464440 (D.S.C. Oct. 26, 2015); Metaphyzic ElEctromagnetic Supreme-El v. Dir., Dep't of Corr., No. 3:14CV52, 2015 WL 1138246 (E.D. Va. Mar. 3, 2015); Best-El Bey v. Paul, No. 3:14-cv-132-FDW, 2014 WL 3749144 (W.D.N.C. July 30, 2014); Nunez v. Atkinson, No. 4:13-2744-TMC-TER, 2014 WL 12526342 (D.S.C. Feb. 18, 2014); United States v. Harding, No. 7:13cr00008, 2013 WL 1832564 (W.D. Va. May 1, 2013); Presley v. Prodan, No. 3:12-3511-CMC-JDA, 2013 WL 1342465 (D.S.C. Mar. 11, 2013); Nash v. Taylor, No. 5:12CV00077, 2012 WL 7766385 (W.D. Va. Dec. 5, 2012); Stevenson v. Keller, No. 1:12CV193, 2012 WL 639515 (M.D.N.C. Feb. 28, 2012); United States v. Mitchell, 405 F. Supp. 2d 602 (D. Md. 2005); Blackstone v. I.R.S., No. CIV. CCB-98-2648, 1998 WL 796738 (D. Md. Sept. 30, 1998).

\section{Fifth Circuit}

United States v. Mesquiti, 854 F.3d 267 (5th Cir. 2017); United States v. Thody, 637 F. App'x 790 (5th Cir. 2016) (mem.); Skinner v. U.S. Dep't of Justice, No. 1:17cv335-HSO-JCG, 2017 WL 6373984 (S.D. Miss. Dec. 12, 2017); Mack v. Sweet, No. 4:17-cv-00434-O-BP, 2017 WL 6756667 (N.D. Tex. Dec. 4, 2017); Laferney v. Parish, No. 2:17-CV-0024, 2017 WL 3493143 (N.D. Tex. Aug. 15, 2017); Wise v. Warden, FCI Texarkana, No. 5:15-CV-45, 2017 WL 2869079 (E.D. Tex. July 5, 2017); Wells Fargo Bank, N.A. v. Parker, No. 4:16-CV-360, 2017 WL 2531748 (E.D. Tex. June 12, 2017); West v. Enns, No. 2:16-CV-0118, 2017 WL 2313469 (N.D. Tex. Apr. 27, 2017); Bruce v. Atlas, No. H-16-3794, 2017 WL 1383894 (S.D. Tex. Apr. 12, 2017); Barcroft v. Gibbs, No. 4:16-CV-00562-ALMCAN, 2017 WL 1499247 (E.D. Tex. Apr. 5, 2017); Mason v. Anderson, No. H-15-2952, 2016 WL 4398680 (S.D. Tex. Aug. 18, 2016); United States v. Sankey, Nos. 3:15-CR-92, 3:07-CR-83, 2016 WL 4253985 (N.D. Tex. July 13, 2016); United States v. Exinia, No. 1:15-CV-41, 2015 WL 12841096 (S.D. Tex. Oct. 9, 2015); Berman v. Stephens, No. 4:14-CV-860-A, 2015 WL 3622694 (N.D. Tex. June 10, 2015); United States v. Weast, No. 4:14-CR-023-A, 2014 WL 12676241 (N.D. Tex. July 15, 2014); United States v. Ernst, No. 10-60109-AA-01, 2012 WL 787221 (N.D. Tex. Mar. 9, 2012); Andrews v. Dretke, No. 3-03-CV-1605-L, 2003 WL 22251084 (N.D. Tex. Sept. 18, 2003); United States v. Solomon, No. 3-98-CV-299-X, 2002 WL 913224 (N.D. Tex. Apr. 29, 2002). 
\begin{tabular}{lllll}
\hline |ljciprod01/productnlMIMON|80-2lMON202.txt & unknown & Seq: 45 & 1-AUG-19 & $11: 52$ \\
\hline
\end{tabular}

\section{Sixth Circuit}

United States v. Coleman, 871 F.3d 470 (6th Cir. 2017); United States v. Pryor, 842 F.3d 441 (6th Cir. 2016); United States v. McCaskill, 48 F. App'x 961 (6th Cir. 2002) (mem.); United States v. Beane, No. 3:17-CR82-TAV-CCS, 2018 WL 493795 (E.D. Tenn. Jan. 19, 2018); United States v. Steele, No. 3:16-cv-00095-GFVT, 2018 WL 298778 (E.D. Ky. Jan. 3, 2018); United States v. Kramer, No. 2:14-cv-2651, 2017 WL 3600443 (S.D. Ohio Aug. 18, 2017); Abdullah v. United States, No. 1:16-cv-1290, 2017 WL 2472591 (W.D. Mich. May 17, 2017); Jackson v. Lazaroff, No. 1:16CV2072, 2017 WL 3098578 (N.D. Ohio June 13, 2017); Muhammad v. Mich. Dep't of Corr., No. 1:17-cv-68, 2017 WL 749343 (W.D. Mich. Feb. 27, 2017); Baird v. Ammiyhuwd, No. 1:16-cv-1152, 2017 WL 430772 (S.D. Ohio Jan. 31, 2017); United States v. Leugers, No. 1:16cv614, 2017 WL 393092 (S.D. Ohio Jan. 30, 2017); Payne v. Klida, No. 15-cv-14127, 2016 WL 491847 (E.D. Mich. Jan. 6, 2016); Zammit v. I.R.S., No.1414155, 2015 WL 8003234 (E.D. Mich. Dec. 7, 2015); United States v. Burnett, No. 3:14-00173, 2015 WL 1906026 (M.D. Tenn. Apr. 20, 2015); Smith v. Heyns, No. 13-14013, 2014 WL 3687119 (E.D. Mich. July 24, 2014); White v. Greene Cty. Sheriff's Dep't, No. 2:09-CV-211, 2014 WL 3058393 (E.D. Tenn. July 7, 2014); Rowe v. Boggs, No. 1:12-cv-647-HJW, 2013 WL 6410556 (S.D. Ohio Dec. 9, 2013); DuBose v. Charles, No. 2:12-cv-971, 2013 WL 12284523 (S.D. Ohio May 29, 2013); DuBose v. Kasich, No. 2:11-CV-00071, 2013 WL 164506 (S.D. Ohio Jan. 15, 2013); United States v. Beavers, 2012 WL 6824151, 2012 WL 6824151 (E.D. Tenn. Dec. 13, 2012); United States v. Ross, No. 3:11-CR-032, 2012 WL 4068579 (E.D. Tenn. Sept. 14, 2012); United States v. Harris, No. 2:09-cr-03, 2009 WL 10681132 (W.D. Mich. Oct. 9, 2009); Goulet v. United States, Nos. 2:08-CV-181, 2:05-CR-08, 2008 WL 2714000 (E.D. Tenn. July 9, 2008); Russell v. Caruso, No. 1:07-cv-662, 2007 WL 3232126 (W.D. Mich. Oct. 30, 2007); Lige v. Gonzales, No. 4:06 CV 1572, 2006 WL 2265524 (N.D. Ohio Aug. 7, 2006); Bellon v. United States Gov't, No. 06-10078-BC, 2006 WL 1134411 (E.D. Mich. Apr. 27, 2006); Devries v. Hammer, No. 1:99CV 111, 1999 WL 1128869 (W.D. Mich. Nov. 4, 1999).

\section{Seventh Circuit}

Moose v. Krueger, No. 16-3954, 2017 WL 3597723 (7th Cir. Apr. 4, 2017) (mem.).

Bey v. State, 847 F.3d 559 (7th Cir. 2017); Walker v. Werlich, No. 162945, 2016 WL 9384216 (7th Cir. Nov. 10, 2016) (mem.); United States v. Banks, 828 F.3d 609 (7th Cir. 2016); United States v. Daniels, 803 F.3d 335 
(7th Cir. 2015); United States v. Anzaldi, 800 F.3d 872 (7th Cir. 2015); United States v. Jonassen, 759 F.3d 653 (7th Cir. 2014); United States v. Ali, 561 F. App'x 544 (7th Cir. 2014) (mem.); United States v. Calderon, 559 F. App'x 554 (7th Cir. 2014); United States v. Pilon, 734 F.3d 649 (7th Cir. 2013); United States v. Davis, 545 F. App'x 513 (7th Cir. 2013); El v. AmeriCredit Fin. Servs., Inc., 710 F.3d 748 (7th Cir. 2013); United States v. Benabe, 654 F.3d 753 (7th Cir. 2011); United States v. Raymond, 228 F.3d 804 (7th Cir. 2000), overruled by Hill v. Tangherlini, 724 F.3d 965 (7th Cir. 2013); United States v. Schneider, 910 F.2d 1569 (7th Cir. 1990); Szach v. Village of Lindenhurst, No. 14 C 7441, 2015 WL 3964237 (N.D. Ill. June 25, 2018); Kayin El v. United States, No. 17-cv-1398-SMY, 2018 WL 659194 (S.D. Ill. Feb. 1, 2018); United States v. Cochran, No. 2:06 CR 114, 2017 WL 5563400 (N.D. Ind. Nov. 20, 2017); Moore v. Kruger, No. 3:16-cv-03295-JBM, 2017 WL 3185843 (C.D. Ill. July 26, 2017); Derrick Family: Hawthorne v. Silverleaf Funding, L.L.C., No. 16 CV 02934, 2017 WL 2573213 (N.D. Ill. June 14, 2017); Hermann v. Wisconsin, No. 17-cv60-jdp, 2017 WL 455445 (W.D. Wis. Feb. 2, 2017);Gilgenbach v. United States Inc., No. 17-cv-01807, 2017 WL 5905281 (N.D. Ill. May 10, 2017); Sundsmo v. Burch, No. 15-cv-2-jdp, 2017 WL 432840 (W.D. Wis. Jan. 31, 2017); Moose v. Krueger, No. 1:16-cv-01403-JBM, 2016 WL 7391513 (C.D. Ill. Dec. 21, 2016); Ellis v. Krueger, No. 1:16-cv-01437-JBM, 2016 WL 6839347 (C.D. Ill. Nov. 21, 2016); Bowman Bey v. Krueger, No. 161412, 2016 WL 6783194 (C.D. Ill. Nov. 16, 2016); United States v. Brown, No. 13 CR 650-1, 2015 WL 7077244 (N.D. Ill. Nov. 13, 2015); Bey v. United States, No. 1:16-cv-01403-JBM, 2016 WL 6238489 (C.D. Ill. Oct. 25, 2016); Gregerson v. Wisconsin, No. 15-cv-549-wmc, 2016 WL 5794811 (W.D. Wis. Oct. 4, 2016); Ladyman v. Meade, No. 3:14 CV 2038, 2016 WL 5466301 (N.D. Ind. Sept. 29, 2016); United States v. Stuart, No. 10-CR-288, 2015 WL 5084403 (E.D. Wis. Aug. 27, 2015); McLendon v. Schwartz, No. 15-cv-586-DRH, 2015 WL 3823718 (S.D. Ill. June 19, 2015); United States v. Bell, No. 13 CR 949-1, 2015 WL 2089000 (N.D. Ill. May 1, 2015); Cruse v. Boey, No. 15-cv-302-DRH, 2015 WL 1726639 (S.D. Ill. Apr. 13, 2015); Sundsmo v. Garrigan, No. 13-cv-682-jdp, 2015 WL 1714365 (W.D. Wis. Apr. 15, 2015); Delatorre v. United States, No. 13 C 1355, 2015 WL 1176820 (N.D. Ill. Mar. 11, 2015); Dudley v. Eggert, No. 1:14-cv-1061-SLD-JEH, 2014 WL 4098141 (C.D. Ill. Aug. 19, 2014); Johnson v. Superintendent, No. 3:14-cv-01546-PPS, 2014 WL 2154421 (N.D. Ind. May 22, 2014); United States v. Jones, No. 11 CR 879, 2014 WL 539384 (N.D. Ill. Feb. 11, 2014); United States v. Sanders, No. 12-cv-96-WDS-SCW, 2013 WL 5567421 (S.D. Ill. May 3, 2013); Johnson v. United States, No. 11-cv-288-DRH, 2013 WL 1728278 (S.D. Ill. Apr. 20, 2013); Westby Co-Op Credit Union v. Hertler, No. 
12-cv-811-wmc, 2012 WL 6195992 (W.D. Wis. Dec. 12, 2012); McDonald-Bey v. Springer, No. 1:12-CV-120, 2012 WL 1424937 (N.D. Ind. Apr. 24, 2012); Golden Ali v. Centralized Infractions Bureau, No. 1:12-CV-53-TLS, 2012 WL 1301239 (N.D. Ind. Apr. 16, 2012); Bank of New York Mellon ex rel. CIT Mortg. Tr. 2007-1 v. Glavin, No. 10-cv-765-slc, 2011 WL 1791599 (W.D. Wis. May 10, 2011); Capital One Bank v. Glavin, No. 10-cv-617-slc, 2011 WL 1211512 (W.D. Wis. Mar. 31, 2011); M\&I Marshall \& Ilsley Bank v. Glavin, No. 10-cv-616-slc, 2011 WL 322663 (W.D. Wis. Jan. 31, 2011); United States v. Johnson, No. 09-CR-20049-DRH, 2009 WL 3672075 (C.D. Ill. Oct. 28, 2009); United States v. Delatorre, No. 03 CR 90, 2008 WL 312647 (N.D. Ill. Jan. 30, 2008); United States v. Kriemelmeyer, No. 07-CR-052-C-01, 2007 WL 5479293 (W.D. Wis. July 26, 2007); Young v. I.R.S., 596 F. Supp. 141 (N.D. Ind. 1984).

\section{Eighth Circuit}

United States v. Hart, 701 F.2d 749 (8th Cir. 1983); United States v. Hardin, 489 F. App'x 984 (8th Cir. 2012) (mem.); United States v. Mooney, No. 16-cv-2547 (SRN/LIB), 2017 WL 2352002 (D. Minn. May 31, 2017); Fullilove v. Glass, No. 4:16CV2143 PLC, 2017 WL 1549776 (E.D. Minn. Apr. 28, 2017); Waldorf v. Dayton, No. 17-107 (JRT/LIB), 2017 WL 1134578 (D. Minn. Mar. 27, 2017); Fisherman v. Minnesota, No. 16-cv2594-DSD-KMM, 2016 WL 7159503 (D. Minn. Nov. 11, 2016); Smith v. M.P. Conway, No. 15-4286, 2016 WL 4727443 (JNE/SER), 2016 WL 4727443 (D. Minn. Sept. 9, 2016); United States v, Garcia, No. 15-cr-260 (PAM/TNL), 2016 WL 9131461 (D. Minn. May 9, 2016); Howard v. James B. Nutter \& Co., No. 4:16CV336 CDP, 2016 WL 1305109 (E.D. Mo. Apr. 4, 2016); Flanagan v. United States, No. 4:13-CV-2090-RWS, 2014 WL 1315230 (E.D. Mo. Mar. 28, 2014); Citi Mortg., Inc. v. Hubbard, No. 13-144 (JRT/JSM), 2014 WL 1303706 (D. Minn. Mar. 31, 2014); Abarca v. United States, No. 4:13CV1573 SNLJ, 2013 WL 4459016 (E.D. Mo. Aug. 19, 2013); United States v. Reed, No. 4:12CR373 AGF (DDN), 2013 WL 11762139 (E.D. Mo. May 2, 2013); United States v. Koss, No. 12-00133-01-CR-W-HFS, 2013 WL 593478 (W.D. Mo. Jan. 25, 2013); United States v. Hobbs, No. 4:12CR14AGF(MLM), 2012 WL 2458425 (E.D. Mo. May 15, 2012); Duwenhoegger v. King, No. 10-3965 (PJS/ JSM), 2012 WL 1516865 (D. Minn. Feb. 13, 2012); United States v. Goodrich, No. 09-00353-10-CR-W-ODS, 2012 WL 7660134 (W.D. Mo. Feb. 10, 2012); Arnold v. United States, No. 1:07CV00160 ERW, 2007 WL 4210475 (E.D. Mo. Nov. 27, 2007); United States v. Knudson, No. 4:CV96-3275, 1997 WL 165689 (D. Neb. Apr. 8, 1997). 


\section{Ninth Circuit}

United States v. Neal, 776 F.3d 645 (9th Cir. 2015); Edwards v. Nevada, No. 2:17-CV-645 JCM (CWH), 2017 WL 5947374 (D. Nev. Nov. 30, 2017); United States v. Agustin-Simon, No. CV 16-2715-PHX-DGC (ESW), 2017 WL 5176683 (D. Ariz. Oct. 5, 2017); Bendeck v. U.S. Bank Nat'l Ass'n, No. 17-00180 JMS-RLP, 2017 WL 2726692 (D. Haw. June 23, 2017); Bendeck v. Workman, No. 17-00180 JMS-RLP, 2017 WL 1758079 (D. Haw. May 4, 2017); Woodruff v. Villalobos, No. 1:16-CV-1170 AWI EPG, 2016 WL 4368004 (E.D. Cal. Aug. 15, 2016); Mackey v. Bureau of Prisons, No. 1:15-cv-1934-LJO-BAM, 2016 WL 3254037 (E.D. Cal. June 14, 2016); United States v. Alexio, Nos. 13-01017 JMS-BMK, 13-01018 JMS-BMK, 2016 WL 1559135 (D. Haw. Apr. 18, 2016); Williams v. Scheingart, No. C 15-3013 MMC, 2015 WL 7351388 (N.D. Cal. Nov. 20, 2015); DIRECTV, L.C.C. v. Scott, No. 2:14-cv-2563-JAM-KJN PS, 2015 WL 4645333 (E.D. Cal. Aug. 4, 2015); United States v. Alexio, Nos. 13-01017 JMS, 13-01018 JMS, 2015 WL 4069160 (D. Haw. July 2, 2015);

Rice v. City of Boise City, No. 1:13-cv-00441-CWD, 2013 WL 6385657 (D. Idaho Dec. 6, 2013); Robertson v. DLJ Mortg. Capital, Inc., No. CV-12-8033-PCT-LOA, 2012 WL 4840033 (D. Ariz. Oct. 11, 2012); Kelly v. Eckert, No. 03:11-cv-00949-HU, 2011 WL 5287339 (D. Or. Sept. 14, 2011); Quigley v. Geithner, No. 1:09-CV-293-REB, 2010 WL 3613901 (D. Idaho Sept. 8, 2010); Heitman v. Idaho State Tax Comm'n, No. CV07-210-E-BLW, 2007 WL 4224053 (D. Idaho Nov. 27, 2007); Heitman v. Bear Lake West Home Owners Ass'n Corp., No. CV-07-209-E-BLW, 2007 WL 4198254 (D. Idaho Nov. 21, 2007); Heitman v. Stone Creek Funding Corp., No. CV-07-150-E-BLW, 2007 WL 3333279 (D. Idaho Nov. 7, 2007); United States v. Stowbunenko-Saitschenko, No. CR 06-0869-PHX-DGC, 2007 WL 865392 (D. Ariz. Mar. 20, 2007); Ray v. Williams, No. CV-04-863-HU, 2005 WL 697041 (D. Or. Mar. 24, 2005); Sherwood v. United States, No. C-96-2223-JSB, 1996 WL 732512 (N.D. Cal. Dec. 9, 1996).

\section{Tenth Circuit}

Carroll v. Moorehead, 710 F. App'x 346 (10th Cir. 2018) (mem.); United States v. Palmer, 699 F. App'x 836 (10th Cir. 2017) (mem.); Charlotte v. Hansen, 433 F. App'x 660 (10th Cir. 2011); Rollins v. Ingersoll-Rand Co., 240 F. App'x 800 (10th Cir. 2007); United States v. Hansen, No. 2:16-cr-534-CW-PMW, 2017 WL 2859929 (D. Utah July 5, 2017); Palmer v. United States, No. 2:16-cv-987, 2017 WL 1533447 (D. Utah Apr. 27, 2017); United States v. Pflum, No. 14-40062-01-DDC, 2016 WL 7242506 (D. Kan. Dec. 15, 2016); Herlocker v. Loffswold, No. 16-2300- 
JAR-TJJ, 2016 WL 5851732 (D. Kan. Oct. 6, 2016); United States v. Rivera, No. CIV 14-0579 JB/CG, 2015 WL 4042197 (D.N.M. June 30, 2015); United States v. Markham, No. 14-10089-JTM, 2015 WL 338967 (D. Kan. Jan. 23, 2015); United States v. Russian, No. 14-CR-10018-EFM, 2014 WL 970066 (D. Kan. Mar. 12, 2014); Utah Dep't of Workforce Serv. v. Geddes, No. 2:13-CV-24 TS, 2013 WL 1367025 (D. Utah Apr. 4, 2013); United States v. Hopkins, No. CIV 11-0416 JB/WPL, 2013 WL 684652 (D.N.M. Feb. 14, 2013); United States v. Jordan, Nos. 06-40160-03-JAR, 12-4047-JAR, 2013 WL 328973 (D. Kan. Jan. 29, 2013); Giron v. Chase Home Mortg. Fin., LLC, No. Civ. 12033 MV/RHS, 2012 WL 13001851 (D.N.M. June 13, 2012); Richmond v. Wampanoag Tribal Court Cases, 431 F. Supp. 2d 1159 (D. Utah 2006); Stamps v. Dieter, Nos. Civ.A. 02-K-956, Civ.A. 02-K-1510, 2002 WL 31476646 (D. Colo. Aug. 30, 2002); In re Tax Indebtedness of Brown, No. C-84-651A, 1984 WL 1356 (D. Utah Nov. 26, 1984).

\section{Eleventh Circuit}

Trevino v. Florida, 687 F. App'x 861 (11th Cir. 2017) (mem.); Walker v. Florida, 688 F. App'x 864 (11th Cir. 2017) (mem.); United States v. Gibson, 633 F. App'x 713 (11th Cir. 2015) (mem.); United Stated v. Davis, 586 F. App'x 534 (11th Cir. 2014) (mem.); United States v. Sellors, 572 F. App'x 628 (11th Cir. 2014) (mem.); Linge v. State of Georgia Inc., 569 F. App'x 895 (11th Cir. 2014) (mem.); United States v. Davis, 549 F. App'x 924 (11th Cir. 2013) (mem.); United States v. Sterling, 738 F.3d 228 (11th Cir. 2013); Frye v. Barbour, No: 2:16-cv-832-FtM-29MRM, 2017 WL 4226531 (M.D. Fla. Sept. 22, 2017); Jackson v. Fla. Dep't of Corr., (FDOC), No. 2:17-cv-321-FtM-99MRM, 2017 WL 3782802 (M.D. Fla. Aug. 31, 2017); Jones v. Georgia, No. 7:17-cv-00116-HL-TQL, 2017 WL 3687657 (M.D. Ga. Aug. 25, 2017); Gibson v. United States, No. 1:13-CR440-TWT-JSA, 2017 WL 4544432 (N.D. Ga. Aug. 24, 2017); Mathis v. Jones, No. 1:15cv130/WTH/CJK, 2017 WL 5633263 (N.D. Fla. June 19, 2017); Greaves v. Mann, No. 1:16-cv-3090-WSD, 2017 WL 510894 (N.D. Ga. Feb. 8, 2017); United States v. Whetstone, 1:09-cr-216-WSD, 2016 WL 6944165 (N.D. Ga. Nov. 28, 2016); Morales v. United States, No. 6:15-cv-636-Orl-37KRS, 2016 WL 6582736 (M.D. Fla. Nov. 7, 2016); Dirden v. Jones, No. 3:15cv412/RV/EMT, 2016 WL 7007547 (N.D. Fla. Oct. 21, 2016); Trevino v. Florida, No: 6:15-cv-2036-Orl-41DAB, 2016 WL 9444258 (M.D. Fla. July 26, 2016); Taylor v. Adduci, No. 7:15-CV1301-JHH-JHE, 2016 WL 3916101 (N.D. Ala. July 20, 2016); Davis v. Fuller, No. 2:15cv169-MHT, 2015 WL 1729379 (M.D. Ala. Apr. 15, 2015); Davis v. Bone, No. 2:15-CV-010-WKW, 2015 WL 1565010 (M.D. Ala. Apr. 8, 2015); Martin v. United States, No. 6:13-cv-8-Orl-22GJK, 
2015 WL 13285000 (M.D. Fla. Mar. 17, 2015); United States v. Garringer, No. 1-14-CR-287-SCJ, 2014 WL 6990309 (N.D. Ga. Dec. 10, 2014); Santiago v. Century 21/PHH Mortg., No. 1:12-CV-02792-KOB, 2013 WL 1281776 (N.D. Ala. Mar. 27, 2013); United States v. Gundy, No. CR 313004, 2013 WL 12212917 (S.D. Ga. Oct. 15, 2013); United States v. Perkins, No. 1:10-cr-97-1-JEC-LTW, 2013 WL 3820716 (N.D. Ga. July 23, 2013); Unites States v. Cartman, No. 1:10-cr-512-01-JEC, 2013 WL 2445158 (N.D. Ga. June 5, 2013); United States v. Baxley, No. 1:13cv38/ MCR/GRJ, 2013 WL 5429301 (N.D. Fla. May 22, 2013); United States v. Dowis, No. 2:12-CR-030-RWS-JCF, 2013 WL 12169389 (N.D. Ga. Mar. 28, 2013); Nunn v. United States, No. 3:13cv12-MHT, 2013 WL 1099321 (M.D. Ala. Feb. 27, 2013); Rufus v. Chapman, No. 3:11-CV-74 (CAR), 2012 WL 4394640 (M.D. Ga. Sept. 24, 2012); United States v. Cordell, No. 4:09-CR-006-CAP-WEJ, 2011 WL 2581018 (N.D. Ga. May 23, 2011); Aboyade-Cole Bey v. BankAtlantic, No. 6:09-cv-1572-Orl-31GJK, 2010 WL 3069102 (M.D. Fla. Aug. 2, 2010); United States v. Luman, No. Civ. 104CV02624CC, 2005 WL 1027075 (N.D. Ga. Apr. 7, 2005); Ruble v. I.R.S., 159 F. Supp. 2d 1381 (N.D. Ga. 2001).

\section{Court of Federal Claims}

Mitchell v. United States, 136 Fed. Cl. 286 (Fed. Cl. 2018); Thomas-Bey v. United States, No. 17-1127C, 2017 WL 6422168 (Fed. Cl. Dec. 18, 2017); Davenport v. United States, No. 17-1122C, 2017 WL 5988354 (Fed. Cl. Dec. 4, 2017); Elleby v. United States, No. 17-351C, 2017 WL 5034471 (Fed. Cl. Nov. 3, 2017); Bechard v. United States, No. 16-1177C (Pro Se), 2017 WL 486946 (Fed. Cl. Feb. 6, 2017); Price v. United States, 123 Fed. Cl. 560 (Fed. Cl. 2015); Headen v. United States, No. 14-673T, 2014 WL 5544093 (Fed. Cl. Nov. 3, 2014); Miles v. United States, Nos. 14-416C; 14-417C; 14-418C; 14-419C \& 14-420C, 2014 WL 5020574 (Fed. Cl. Oct. 6, 2014); Rivera v. United States, 105 Fed. Cl. 644 (Fed. Cl. 2012); Cooper v. United States, 104 Fed. Cl. 306 (Fed. Cl. 2012); Gravatt v. United States, 100 Fed. Cl. 279 (Fed. Cl. 2011); Davis v. United States, No. 09-862C, 2010 WL 1685907 (Fed. Cl. Apr. 22, 2010); Fuce v. United States, No. 06-269 T, 2006 WL 2808072 (Fed. Cl. Aug. 25, 2006); Withers v. United States, No. 06-64C, 2006 WL 5640831 (Fed. Cl. June 14, 2006).

\section{Federal Circuit}

Ingalls Shipbuilding, Inc. v. United States, 13 Cl. Ct. 757 (Cl. Ct. 1987), rev'd, 857 F.2d 1448 (Fed Cir. 1988). 


\begin{tabular}{lllll}
\hline Iljciprod01/productnlMIMON180-2lMON202.txt & unknown & Seq: 51 & 1-AUG-19 & $11: 52$ \\
\hline
\end{tabular}

2019 LEGAL RESPONSE TO SOVEREIGN CITIZEN MOVEMENT 203

\section{Tax Court}

Harris v. Comm'r, T.C. Memo. 2012-275, 2012 WL 4464549 (2012).

\section{D.C. Circuit}

Magritz v. Ozaukee Cty., No. 12-806 (EGS), 2012 WL 3744724 (D.C. Aug. 30, 2012); Maxwell v. Snow, 409 F.3d 354 (D.C. Cir. 2005); Manson v. United States, No. 00CV00272, 2001 WL 241799 (D.C. Cir. Feb. 2, 2001); Ellena v. Flournoy, No. 92-1263, 1992 WL 234977 (D.C. Aug. 26, 1992). 
ApPENDIX II

\section{Redemption Scheme}

\section{First Circuit}

United States v. Sayer, 450 F.3d 82 (1st Cir. 2006).

\section{Second Circuit}

United States v. Li, 115 F.3d 125 (2d Cir. 1997); United States v. Blusal Meats, Inc., 817 F.2d 1007 (2d Cir. 1987); TGS-NOPEC Geophysical Co. v. Merrill Lynch, Pierce, Fenner \& Smith, Inc., No. 08 Civ. 10950(SAS), 2009 WL 185995 (S.D.N.Y. Jan. 26, 2009); 9Oak Beverages, Inc. v. Tomra of Mass., L.L.C., 6 F. Supp. 2d 336 (S.D.N.Y 2000).

\section{Third Circuit}

United States v. Thach, 411 F. App'x 485 (3d Cir. 2011); Monroe v. Beard, 536 F.3d 198 (3d Cir. 2008); Lewicki v. Washington Cty., 431 F. App'x 205 (3d Cir. 2001); Belt v. U.S. Dep't of Justice, No. 4:CV-10-2339, 2011 WL 13196525 (M.D. Pa. Jan. 31, 2011); Rousseau v. U.S. Dep't of Treasury, No. 04-4368 (MLC), 2010 WL 457702 (D.N.J. Feb. 5, 2010); In re Penn. Cent. Transp. Co., 458 F. Supp. 1364 (E.D. Pa. 1978).

\section{Fourth Circuit}

United States v. Able, No. 3:09-537-JFA-PJG, 2010 WL 2431013 (D.S.C. Mar. 26, 2010).

\section{Sixth Circuit}

United States v. Smith, 39 F.3d 119 (6th Cir. 1994), superseded by regulation, 18 U.S.C. § 3A1.1, as stated in United States v. McCaster, 333 F. App'x 970 (6th Cir. 2009); United States v. Bahhur, 200 F.3d 917 (6th Cir. 2000); Elfelt v. United States, 149 F. App'x 402 (6th Cir. 2005) (mem.); In re Sadler, No. 1:14CV2312, 2015 WL 9474174 (N.D. Ohio Dec. 29, 2015); Siddle v. Crants, No. 3:09-0175, 2010 WL 424906 (M.D. Tenn. Jan. 25, 2010); Zebari v. Pepsi Bottling Co., No. 05-CV-72924, 2007 WL 1675178 (E.D. Mich. June 11, 2007).

\section{Seventh Circuit}

United States v. Dilley, No. 1:08-CR-37, 2009 WL 1564389 (N.D. Ind. June 3, 2009); United States v. Manasrah, 347 F. Supp. 2d 634 (E.D. Wis. 2004); Shapo v. O’Shaughnessy, 246 F. Supp. 2d 935 (N.D. Ill. 2002); 
Small ex rel. Day Surgicenters, Inc. v. Sussman, No. 94 C 5200, 1995 WL 153327 (N.D. Ill. Apr. 5, 1995); First Nat'l Bank of Chicago as Tr. of Institutional Real Estate Fund F v. ACCO USA, Inc.-IBT Ret. Plan, 842 F. Supp. 311 (N.D. Ill. 1994); In re Carter, 312 B.R. 356 (Bankr. N.D. Ill. 2004).

\section{Eighth Circuit}

Fehrs Fin. Co. v. Comm'r, 487 F.2d 184 (8th Cir. 1973); Resolution Tr. Corp. v. Bermel Inv. Co., No. 3-90-448, 1991 WL 557610 (D. Minn. May 1, 1991); Justice v. Valley Nat'l Bank, 849 F.2d 1078 (8th Cir. 1988); In re Lally, 51 B.R. 204 (Bankr. N.D. Iowa 1985); In re Lally, 38 B.R. 622 (Bankr. N.D. Iowa 1984).

\section{Ninth Circuit}

United States v. Van Krieken, 39 F.3d 227 (9th Cir. 1994), superseded by statute, 26 U.S.C. § 7212, as stated in United States v. McEnry, 659 F.3d 893 (9th Cir. 2011); United States v. Lorenzo, 995 F.2d 1448 (9th Cir. 1993); Dupnik v. United States, 848 F.2d 1476 (9th Cir. 1986); United States v. Call, No. 2:09-cr-00079-KJD-RJJ, 2009 WL 6047137 (D. Nev. Nov. 24, 2009); In re Larson, 99 B.R. 1 (Bankr. D. Alaska 1989).

\section{Tenth Circuit}

United States v. Brewer, 983 F.2d 181 (10th Cir. 1993).

\section{Eleventh Circuit}

Sec. and Exch. Comm'n v. Conrad, No. 1:16-CV-02572-LMM, 2017 WL 3500364 (N.D. Ga. May 2, 2017); United States v. Jenkins, No. 1:11-CR-27 (WLS), 2013 WL 3245206 (M.D. Ga. June 26, 2013); United States v. Sellers, No. 5:11-cv-326-RS-CJK, 2013 WL 3746102 (N.D. Fla. Apr. 30, 2013); First Fin. Bank v. CS Assets, L.L.C., No. 08-0731-WS-M, 2010 WL 114531 (S.D. Ala. Jan. 13, 2010).

\section{Tax Court}

Estate of Holtzin v. Comm'r, T.C. Memo. 1995-299 (1995); Pelton Steel Casting Co. v. Comm'r, 28 T.C. 153 (1957); Brown \& Williamson Tobacco Corp. v. Comm'r, 16 T.C. 432 (1951). 
APPENDIX III

\section{Right to Travel}

\section{Fourth Circuit}

Nash v. Taylor, No. 5:12CV00077, 2012 WL 7766385 (W.D. W.Va. Dec. 5, 2012).

\section{Fifth Circuit}

Sochia v. United States, No. Civ.A.SA-04-CA-0612, 2004 WL 1790170 (W.D. Tex. Aug. 11, 2004); Sochia v. Fed. Republic's Cent. Gov't, No. SA06-CA-1006-XR, 2006 WL 3372509 (W.D. Tex. Nov. 20, 2006).

\section{Sixth Circuit}

Matthews v. United States, No. 3:16cv00148, 2016 WL 2624974 (S.D. Ohio May 9, 2016).

\section{Seventh Circuit}

Szach v. Village of Lindenhurst, No. 14 C 7441, 2015 WL 3964237 (N.D. Ill. June 25, 2015).

\section{Ninth Circuit}

Vazquez v. Cal. Highway Patrol, No. 2:15-cv-756-JAM-EFB PS, 2016 WL 232332 (E.D. Cal. Jan. 19, 2016).

\section{Tenth Circuit}

Secor v. Oklahoma, No. 16-CV-85-JED-PJC, 2016 WL 6156316 (N.D. Okla. Oct. 21, 2016).

\section{Eleventh Circuit}

Hyppolite v. Broward Sheriff's Office, No. 16-61215-Civ-COOKE/ TORRES, 2017 WL 2691978 (S.D. Fla. June 2017).

\section{California}

Halajian v. D \& B Towing, 209 Cal. App. 4th 1 (Cal. Ct. App. Sept. 4, 2012). 


\begin{tabular}{lllll}
\hline I.jciprod01/productnlMIMONI80-2LMON202.txt & unknown & Seq: 55 & 1-AUG-19 & $11: 52$ \\
\hline
\end{tabular}

2019 LEGAL RESPONSE TO SOVEREIGN CITIZEN MOVEMENT 207

\section{Hawai'i}

State v. French, 883 P.2d 644 (Haw. App. 1994).

\section{Ohio}

Mt. Vernon v. Young, No. 2005CA000045, 2006 WL 1781478 (Ohio Ct. App. June 28, 2006); Ralph v. Behr, No. 16 CA 42, 2017 WL 1464838 (Ohio Ct. App. Apr. 17, 2017).

\section{Pennsylvania}

Commonwealth v. Boll, No. 653 MDA 2017, 2017 WL 6545573 (Pa. Super. Ct. Dec. 22, 2017); Commonwealth v. Bey, No. 197 MDA 2013, 2013 WL 11253378 (Pa. Super. Ct. Oct. 30, 2013).

\section{Texas}

Meyer v. State, No. 06-16-00078-CR, 2016 WL 7321444 (Tex. App. Dec. 16, 2016); Avery v. Baddour, No. 04-16-00184-CV, 2016 WL 4208115 (Tex. App. Aug. 10, 2016); In re Meyer, 482 S.W.3d 706 (Tex. App. Jan. 14, 2016). 
APPENDIX IV

\section{Fringe on Flags}

\section{Second Circuit}

United States v. Robinson, No. 08 Cr. 976 (NRB), 2015 WL 8073757 (S.D.N.Y. Dec. 4, 2015); Parker v. New York, No. 05 Civ.3347(GWG), 2006 WL 864272 (S.D.N.Y. Apr. 5, 2006); Ha v. Deutsche Bank N.J. Serv., Inc., No. 03Civ.8180(KMW)(RLE), 2005 WL 589408 (S.D.N.Y. Mar. 11, 2005); Diaz v. Deboo, No. 3:04CV1321(SRU), 2004 WL 1944021 (D. Conn. Aug. 31, 2004); Joyner v. Borough of Brooklyn, No. $98 \mathrm{CV}$ 2579(RJD), 1999 WL 294780 (E.D.N.Y. Mar. 18, 1999); Rogers v. Borough of Manhattan, No. 98 Civ 2907(DLC), 1998 WL 704003 (S.D.N.Y. Oct. 1, 1998); United States v. Warren, No. 91-CR-226, 1998 WL 26406 (N.D.N.Y. Jan. 22, 1998).

\section{Third Circuit}

Prout v. Margetas, 2013 WL 3273389, 2013 WL 3273389 (M.D. Pa. June 27, 2013); United States v. Ramos, No. CRIM.A. 03-379, 2004 WL 356412 (E.D. Pa. Feb. 5, 2004).

\section{Fourth Circuit}

United States v. Harding, No. 7:13cr00008, 2013 WL 1832564 (W.D. Va. May 1, 2013).

\section{Fifth Circuit}

Abel v. Bank of Winona, No. 4:16-CV-00068-DMB-JMV, 2016 WL 3580757 (N.D. Miss. June 28, 2016); United States v. Greenstreet, No. 2:95-CV-119-J, 912 F. Supp. 224 (N.D. Tex. 1996); Vella v. McCammon, 671 F. Supp. 1128 (S.D. Tex. 1987).

\section{Sixth Circuit}

Lowery v. Ohio, No. 1:14 CV 2523, 2015 WL 1885456 (N.D. Ohio Apr. 24, 2015); Buess v. I.R.S., No. 3:14-cv-0826, 2014 WL 5091738 (N.D. Ohio Oct. 9, 2014); DuBose v. Kasich, No. 2:11-CV-00071, 2013 WL 164506 (S.D. Ohio Jan. 15, 2013); Murdock v. Am. Axle \& Mfg., Inc., No. 03-CV-73744-DT, 2003 WL 25816431 (E.D. Mich. Dec. 23, 2003); Irving v. Lorson, No. C-2-02-823, 2002 WL 31844685 (S.D. Ohio Dec. 12, 2002). 


\section{Seventh Circuit}

United States v. Benabe, 654 F.3d 753 (7th Cir. 2011).

\section{Eighth Circuit}

Obregon v. Hollenback, No. 5:15-HC-2098-FL, 2015 WL 12912376 (E.D.N.C. Oct. 1, 2015); United States v. Montgomery, No. 10-00187-01-CR-W-ODS, 2011 WL 976555 (W.D. Mo. Feb. 22, 2011); Klaudt v. Dooley, No. Civ. 10-4091-KES, 2010 WL 5391571 (D.S.D. Dec. 22, 2010); Christian Sci. Bd. of Dir. of First Church of Christ, Scientist v. Robinson, 123 F. Supp. 2d 965 (W.D.N.C. 2000); Cass v. Richard Joshua Reynolds Tobacco Co., No. 1:97CV01236, 1998 WL 834856 (M.D.N.C. Oct. 1, 1998); McCann v. Greenway, 952 F. Supp. 647 (W.D. Mo. 1997); In re Recker, No. 09-01541, 2010 WL 3655516 (Bankr. N.D. Iowa Sept. 10, 2010).

\section{Ninth Circuit}

Springer v. Hunt, No. 17-00269 JMS-KSC, 2017 WL 3380675 (D. Haw. Aug. 4, 2017); Access Capital Inv. Fund Two, L.P. v. Pujol, No. C 15-0312 MMC, 2015 WL 1089329 (N.D. Cal. Mar. 3, 2015); Wilson v. Super. Ct. of Cal. Tuolumne Cty., No. 1:13-cv-01587-LJO-SAB-HC, 2014 WL 51158 (E.D. Cal. Jan. 7, 2014); Vasile v. Nooth, No. 09-71-AC, 2011 WL 846693 (D. Or. Feb. 17, 2011); Sunbelt Towing, Inc. v. Moore, No. 08cv1437 WQH (BLM), 2008 WL 4791841 (S.D. Cal. Nov. 3, 2008); In re GSM Wireless, Inc., No. 2:12-bk-16456 RK, slip op. (Bankr. C.D. Cal. Apr. 5, 2013).

\section{Tenth Circuit}

United States v. Mackovich, 209 F.3d 1227 (10th Cir. 2000); United States v. Blackburn, No. 09-20133, 2010 WL 5185390 (D. Kan. Dec. 15, 2010); Sadlier v. Payne, 974 F. Supp. 1411 (D. Utah Aug. 26, 1997).

\section{Eleventh Circuit}

United States v. Carpa, 271 F.3d 962 (11th Cir. 2001); Schneider v. Schlaefer, 975 F. Supp. 1160 (E.D. Wis. 1997).

\section{United States Court of Claims}

Am. Exp. Isbrandtsen Lines, Inc. v. United States, 499 F.2d 552 (Ct. Cl. 1974); Pewee Coal Co. v. United States, 161 F. Supp. 952 (Ct. Cl. 1958). 
Montana Law Review, Vol. 80 [2019], Iss. 2, Art. 2

\begin{tabular}{lllll}
\hline Iljciprod01|productnIMIMON|80-2LMON202.txt & unknown & Seq: 58 & 1-AUG-19 & $11: 52$ \\
\hline
\end{tabular}

